\title{
Studying Neutrophil Function in vitro: Cell Models and Environmental Factors
}

This article was published in the following Dove Press journal:

Journal of Inflammation Research

\section{Marfa Blanter (iD \\ Mieke Gouwy (D) \\ Sofie Struyf}

Laboratory of Molecular Immunology, Department of Microbiology, Immunology and Transplantation, Rega Institute for Medical Research, University of Leuven, Leuven 3000, Belgium
Correspondence: Sofie Struyf Rega Institute - Herestraat 49 - Bus 1042, Leuven 3000, Belgium

Tel +32 16322422

Email sofie.struyf@kuleuven.be

\begin{abstract}
Neutrophils are the most abundant immune cell type in the blood and constitute the first line of defense against invading pathogens. Despite their important role in many diseases, they are challenging to study due to their short life span and the inability to cryopreserve or expand them in vitro. Thus, research into neutrophils has to rely on cells freshly isolated from peripheral blood of human donors, introducing donor-dependent variation in the experimental data. To counteract these problems, researchers tried to develop adequate cell models, such as cell lines. For those functional studies that cannot rely on cell models, a standardization of protocols regarding neutrophil purification and culturing could be a solution. In this review, we provide an overview of the most commonly used models for neutrophil function (HL-60, PLB-985, NB4, Kasumi-1 and induced pluripotent stem cells). In addition, we describe the effects of glucose concentration, $\mathrm{pH}$, oxygen tension and temperature on neutrophil function.
\end{abstract}

Keywords: neutrophils, HL-60, PLB-985, NB4, Kasumi-1, induced pluripotent stem cells

\section{Introduction}

Neutrophils belong to the group of granulocytes, which are members of the innate immune system and constitute the most abundant leukocyte subtype circulating in blood. Neutrophils develop in the bone marrow from granulocyte-monocyte progenitor cells (GMPs), the same cells that give rise to monocytes, dendritic cells and other granulocytes. GMPs originate from hematopoietic stem cells and are committed to the myeloid lineage. ${ }^{1}$ The stepwise development of neutrophils from GMPs is called granulopoiesis (Figure 1). ${ }^{1}$ Terminally differentiated neutrophils have lost their capacity to proliferate and can therefore not be expanded in culture.

Neutrophils owe their name to their balanced uptake of hematoxylin and eosin, which distinguishes them from other granulocytes: eosinophils and basophils. ${ }^{1}$ Another distinctive feature of neutrophils is their segmented nucleus and a cytoplasm filled with granules. Based on the biosynthesis of the granules during the maturation of neutrophils in the bone marrow, the granules can be classified into the following three categories: azurophilic (primary) granules, specific (secondary) granules and gelatinase (tertiary) granules. Examples of azurophilic granule proteins are myeloperoxidase (MPO), neutrophil elastase (NE) and cathepsin G; examples of specific granule proteins are lactoferrin and CD66b; and examples of gelatinase granule proteins are matrix metalloproteinase 9 (MMP-9) and CD11b. In addition, neutrophils contain secretory vesicles, which are mainly filled with surface receptors, ready to be mobilized to the plasma membrane. ${ }^{2}$

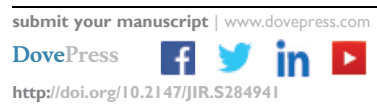




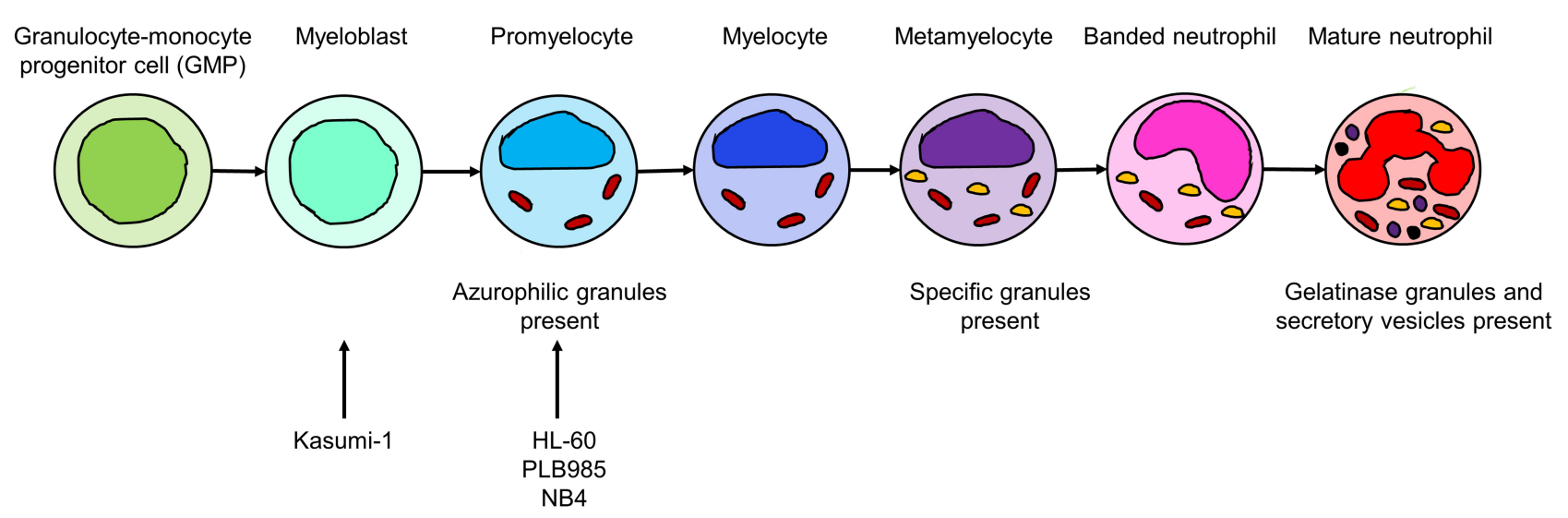

Figure I Granulopoiesis. In the process of granulopoiesis, neutrophils develop stepwise from granulocyte-monocyte progenitor cells (GMPs). Each stage has a unique phenotype that is comprised of both morphologic features and cell surface markers. In the first step, the cell transitions into the myeloblast stage. The promyelocyte stage is characterized by the appearance of azurophilic granules. Specific granules start to develop at the myelocyte stage, and are fully present at the metamyelocyte stage; this is also the point at which the cell loses its proliferative capacity. After the metamyelocyte stage, the cell can be called a neutrophil; it acquires the distinctive banded nucleus and develops gelatinase granules and secretory vesicles. ${ }^{2}$ The arrows indicate the stage of the cell lines that are discussed in this paper.

All of the granules are crucial for pathogen killing, as their contents can either be excreted into the extracellular space or fused with phagosomes, facilitating destruction of phagocytosed material inside the cell. ${ }^{2}$ Azurophilic granules are mostly involved in phagosome formation; specific granules are involved in both phagosome formation and exocytosis; and gelatinase granules and secretory vesicles are mostly involved in exocytosis. ${ }^{3}$ The action of granules is supported by the production of reactive oxygen species (ROS), which can also damage pathogens both intracellularly and extracellularly. Another mechanism that neutrophils employ to fight infection, is the expulsion of neutrophil extracellular traps (NETs): strands of DNA mixed with histones and granule proteins, which can immobilize and kill pathogens. Finally, neutrophils can produce various cytokines, which attract other immune cells to the site of inflammation. Together, these mechanisms ensure efficient pathogen killing and host defense (Figure 2). For a more detailed overview of neutrophil function, the reader is referred to Ley et $\mathrm{al}^{4}$.

For a long time, neutrophils were considered to be a large pool of identical cells, destined to use their weapons on invading pathogens as fast as possible and quickly die afterwards. Now we know, however, that neutrophils are not identical but can be classified into different subsets based on parameters such as density, function and maturation stage.

Perhaps the clearest distinction can be made between immature, mature and activated neutrophils. Immature neutrophils mostly reside in the bone marrow but can be released into the blood stream under acute inflammatory conditions following a process called emergency granulopoiesis. ${ }^{5}$ They can be distinguished from mature and aged neutrophils by the presence of a banded nucleus and the expression levels of CD16, CD62L and CD10 $\left(\mathrm{CD} 16^{\text {low }} / \mathrm{CD} 62 \mathrm{~L}^{\text {high }} / \mathrm{CD} 10^{-}\right)^{6,7}$ The exit of neutrophils from the bone marrow is regulated by the balance between CXCR2 and CXCR4 signaling. CXCR4 is the receptor for CXCL12, a chemokine highly expressed in the bone marrow. CXCR2 responds to multiple CXC chemokines, including CXCL8, the major neutrophil-attracting chemokine. As neutrophils mature in the bone marrow, they gradually lose surface expression of CXCR4 and upregulate CXCR2, allowing them to exit the bone marrow into the blood stream. ${ }^{8}$ Mature neutrophils constitute the majority of circulating neutrophils in the blood stream, and can be distinguished by a clearly segmented nucleus. They are $\mathrm{CD} 16^{\text {high }} / \mathrm{CD} 62 \mathrm{~L}^{\text {high }} / \mathrm{CD} 10^{+} .6,7$ With time, mature neutrophils become aged, acquiring a hypersegmented nucleus and a $\mathrm{CD} 16^{\text {high }} / \mathrm{CD} 62 \mathrm{~L}^{\text {low } /}$ CD $10^{+}$phenotype. ${ }^{6,7}$ Following a circadian rhythm, aged neutrophils upregulate CXCR4; this ensures that they can home back to the bone marrow, where they undergo apoptosis and are degraded by resident macrophages. ${ }^{8,9}$ Aged neutrophils can also be found in tissues, from where they can retreat back into the bloodstream in a process called reverse transendothelial migration. ${ }^{10}$

It has been suggested that neutrophils of different stages display different functional properties. For example, immature neutrophils show an improved intracellular killing of bacteria compared to mature or hypersegmented neutrophils, and aged neutrophils in mice have been 


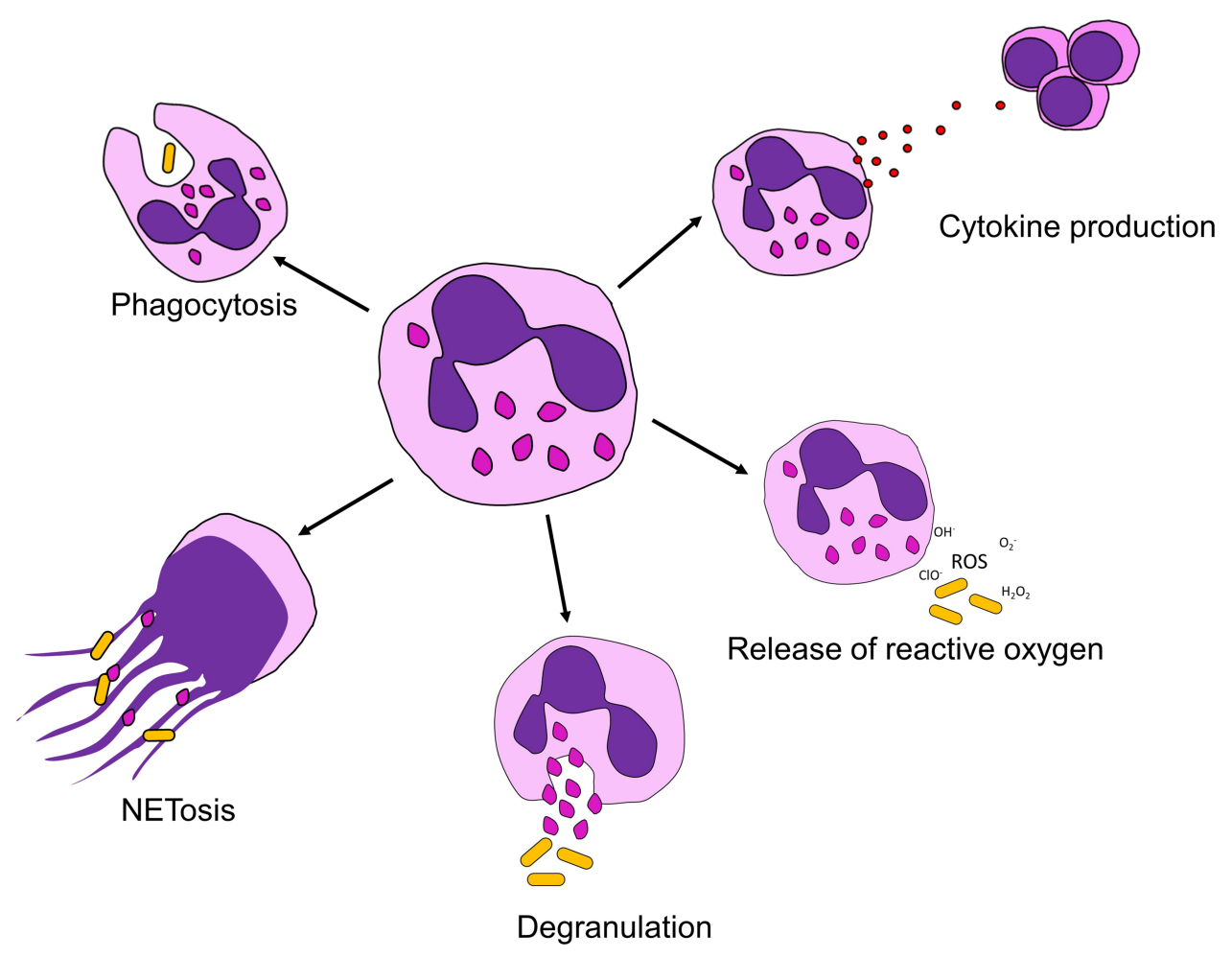

Figure 2 Neutrophil functions. To combat infection, neutrophils can execute various functions. Phagocytosis is the uptake of pathogens inside the cell. NETosis is a form of cell death in which neutrophils expulse their DNA together with histones and granular proteins (neutrophil extracellular traps). During degranulation, neutrophils release enzymes and antibacterial peptides which are normally stored inside granules. During the release of reactive oxygen species, neutrophils convert oxygen to highly reactive forms that are capable of damaging pathogens. Finally, neutrophils release cytokines, activating other immune cells and attracting them to the site of infection.

shown to be faster in reaching the tissues upon induction of acute inflammation. ${ }^{11,12}$ In addition, $\mathrm{CD}^{-} 0^{-}$neutrophils have been shown to promote $\mathrm{T}$ cell proliferation in vitro, whereas $\mathrm{CD} 10^{+}$neutrophils suppress it. ${ }^{13}$ Whether these differences in function have any clinical relevance remains to be discovered.

Another classification is based on the density of neutrophils. During density gradient-based neutrophil purification, whole blood is loaded onto a polysaccharide-containing solution with a density of $1.077 \mathrm{~g} / \mathrm{mL}$ (eg, Ficoll). After centrifugation, granulocytes and erythrocytes can be found under the polysaccharide layer, whereas peripheral blood mononuclear cells (PBMC) form a band above it. Research has shown that a small percentage of neutrophils end up in the PBMC layer and are referred to as low-density neutrophils (LDNs), as opposed to the "conventional" normaldensity neutrophils (NDNs). ${ }^{14}$ The percentage of LDNs in healthy individuals is very low, but in several diseases, including systemic lupus erythematosus (SLE) and rheumatoid arthritis, the proportion of LDNs is significantly increased. ${ }^{15,16}$ Various findings suggest that the LDNs can have different identities. LDNs can be either immature cells released from the bone marrow, or they can be mature cells that have degranulated; in the latter case, the degranulation can have occurred in the blood stream, or it can have occurred in tissue, followed by reverse transmigration of the neutrophils into the bloodstream. ${ }^{14}$ Depending on the disease context, LDNs can have both pro-inflammatory and immunosuppressive functions, although more research is needed to understand what determines their functional profile. $^{17}$

In mice, tumor-associated neutrophils have been shown to polarize towards an N1 or N2 phenotype. ${ }^{18} \mathrm{~N} 1$ neutrophils are pro-inflammatory and highly cytotoxic, producing vast amounts of ROS and activating the adaptive immune system. In contrast, N2 neutrophils are immunosuppressive and promote tumor growth and metastasis by producing angiogenic factors and enzymes that degrade extracellular matrix. Tumors can actively recruit neutrophils and transform them to the N2 phenotype through the production of transforming growth factor $\beta$ (TGF- $\beta$ ). Blocking TGF- $\beta$ or administering interferon $\beta$ (IFN- $\beta$ ) promotes neutrophil polarization towards $\mathrm{N} 1 .^{18}$

In addition to pro-tumoral N2 neutrophils, tumor growth can also be promoted by myeloid-derived suppressor cells (MDSCs). ${ }^{19}$ MDSCs are generally categorized, 
based upon expression of monocytic or granulocytic markers, into M-MDSCs and PMN-MDSCs, respectively, but are best defined by immune regulatory activity, eg, suppression of the proliferation and activation of cytotoxic T lymphocytes. ${ }^{20,21}$ PMN-MDSCs are typically immature and phenotypically very similar to other neutrophils. Several MDSC-specific markers have been described, including lectin-type oxidized LDL receptor-1 (LOX-1) and secreted protein acidic and rich in cysteine (SPARC). ${ }^{22,23}$ MDSCs develop in the bone marrow, but can be actively recruited by solid tumors, where they are activated and directed against $\mathrm{T}$ lymphocytes. ${ }^{21}$ Various ongoing clinical trials employ inhibition of MDSC protumorigenic activity to treat cancer. ${ }^{19}$ Apart from cancer, MDSCs are involved in a range of other diseases, including infectious diseases and autoimmunity. ${ }^{24-26}$

Other neutrophil subsets have been proposed, including $\mathrm{CD}_{177^{+}}$(approximately half of peripheral blood neutrophils) and OLFM4 ${ }^{+}$(approximately a quarter of peripheral blood neutrophils) cells; however, more research is needed to determine their functional properties. ${ }^{17}$

While neutrophils play an important role in many diseases, including infection, autoimmunity and cancer, they pose a challenge for those trying to study them. ${ }^{27-29}$ The average half-life of a neutrophil in the blood stream comprises only $6-8 \mathrm{~h}$, and after purification of neutrophils from the blood the cells quickly go to apoptosis. ${ }^{30,31}$ Neutrophils do not proliferate, making it impossible to expand them in vitro; and cryopreservation of these cells has so far not been proven successful. ${ }^{1}$ Thus, research into neutrophils has to rely on cells freshly isolated from peripheral blood of human donors. This introduces donor-dependent variation in the experimental data. To counteract these problems, researchers tried to develop adequate neutrophil models, such as cell lines. For those functional studies that cannot rely on cell models, a standardization of protocols regarding neutrophil purification and culturing could be a solution. In this review, we provide an overview of the most commonly used models for neutrophil research. In addition, we describe the effects of glucose concentration, $\mathrm{pH}$, oxygen tension and temperature on neutrophil function.

\section{The HL-60 Cell Line as a Model for Human Neutrophils}

The most commonly used cell line in neutrophil research is the HL-60 cell line, derived from a female Caucasian patient with acute promyelocytic leukemia. ${ }^{32,33}$ HL-60 is a suspension cell line which does not require growth supplements and proliferates relatively fast (doubling time $20-45$ hours). A big advantage of HL-60 cells is that they are permissive to a range of genetic editing techniques, including lentiviral transduction, lipofectamine transfection, electroporation and nucleofection. ${ }^{34-38}$ Importantly, HL-60 cells can be differentiated into neutrophil-like cells by treating them with all-trans retinoic acid (ATRA), polar-planar compounds (eg, dimethyl sulfoxide [DMSO] and dimethylformamide [DMF]), actinomycin D or dibutyryl cyclic AMP (dbcAMP). ${ }^{39-43}$ Other compounds (eg, vitamin D) may lead to differentiation towards a more monocytic phenotype. ${ }^{44}$

\section{Differentiation of HL-60 Cells into Granulocytes}

The uncontrolled growth and lack of differentiation in HL60 cells is largely dependent on the c-Myc gene. ${ }^{45} \mathrm{c}-\mathrm{Myc}$ is a transcription factor that controls cell differentiation, proliferation and apoptosis. While expression of c-Myc is high in all proliferating cells, it is rapidly downregulated upon terminal differentiation; not surprisingly, therefore, dysregulated c-Myc has been found in many types of cancer. ${ }^{46}$ In HL-60 cells, there is a more than ten-fold genomic amplification of c-Myc, which can be present both inside the chromosomes and in extrachromosomal structures. ${ }^{45,47,48}$ Interestingly, the extra copies have been shown to be more stable in later passages of HL-60 cells, correlating with a reduction in doubling time. ${ }^{48} \mathrm{~A}$ small percentage of the cell population differentiates spontaneously into granulocyte-like cells; these spontaneous granulocytes have been shown to have less c-Myc DNA than their undifferentiated sister cells. ${ }^{49}$ It is likely, however, that c-Myc is not the only player in the cancerous phenotype of HL-60 cells, as inhibition of c-Myc alone reduces proliferation and survival but does not necessarily result in granulocytic differentiation. ${ }^{50,51}$

Compounds most commonly used to differentiate HL60 cells into granulocytes are ATRA and DMSO. ${ }^{39,40}$ ATRA is a derivative of vitamin A, which binds preferentially to the retinoic acid receptor A (RAR $\alpha){ }^{52}$ Of note, vitamin A can be metabolized into both ATRA and 9-cisretinoic acid, both of which have different physiological properties. However, older studies describing HL-60 differentiation often make no distinction between the two, using the more generic term retinoic acid (RA). The effects of ATRA on normal adult hematopoiesis seem to 
differ depending on the context; thus, it can both induce and inhibit proliferation and differentiation of neutrophil precursors. ${ }^{53}$ ATRA-induced differentiation mechanisms in HL-60 cells can be divided into receptor-dependent and receptor-independent effects. Receptor-dependent effects are mediated by RAR $\alpha$. RAR $\alpha$ is a nuclear receptor, which initiates gene transcription upon ligand binding. ${ }^{52}$ Activation of RAR $\alpha$ by ATRA initiates multiple signaling pathways, among which the MAPK and the PI3K/Akt pathways. ${ }^{54,55}$ This ultimately results in growth arrest and cytoskeletal reorganizations needed for differentiation. ${ }^{56}$ In addition to these receptor-mediated effects, ATRA has been shown to block the transcription of c-Myc in a receptor-independent fashion. ${ }^{57}$

The mechanisms by which DMSO induces HL-60 differentiation are much less clear. It is known that DMSO can induce a transcription elongation block of the c-Myc gene and inhibit its splicing upon prolonged exposure. ${ }^{58} \mathrm{In}$ addition, DMSO has the capacity to eliminate extrachromosomal structures containing amplified c-Myc gene. ${ }^{59}$ Finally, DMSO has been shown to upregulate several kinases involved in intracellular signaling pathways, including Ras (involved in the MAPK pathway) and protein kinase $\mathrm{C}$ (PKC). ${ }^{60,61}$

Further in this paper, we will refer to undifferentiated HL-60 cells as uHL-60, and to differentiated HL-60 as dHL-60, either or not preceded by the specific differentiation agent (eg, DMSO-dHL-60). The complete overview of functions executed by dHL-60 cells is summarized in Table 1.

\section{HL-60 Cells to Study Chemotaxis \\ Chemotaxis in Neutrophils - An Overview}

Chemotaxis is the directional movement of a cell along a chemical gradient. In order to migrate, the cell first needs to sense the presence of an inflammatory environment. While travelling through the blood vessels, neutrophils constantly attach and detach from the endothelial cell wall, a process called rolling. Rolling is mediated by three types of selectins: L-selectin (CD62L, present on leukocytes), E-selectin (present on endothelial cells) and P-selectin (present on endothelial cells and activated platelets). Selectins can bind to various ligands, the most studied of which is P-selectin glycoprotein ligand1 (PSGL-1). ${ }^{62}$ Selectin-mediated interaction between neutrophils and endothelial cells is relatively weak, but during inflammation, release of various mediators (eg, tumor necrosis factor $\alpha$ [TNF- $\alpha$ ], interleukin-1 $\beta$ [IL-1 $\beta]$ ) upregulates the expression of E-selectin, resulting in stronger binding. ${ }^{62}$ The process of rolling ensures that neutrophils can come in contact with chemokines (chemotactic cytokines), which are captured on glycosaminoglycans (GAGs) on the surface of endothelial cells. ${ }^{63}$ The chemokines then bind to their receptors on the

Table I Functions Which Differentiated HL-60 Cells are Capable of Executing

\begin{tabular}{|c|c|c|c|}
\hline Function & Stimulus & Differentiation Agent & References \\
\hline Cell polarization & $\begin{array}{l}\text { fMLF } \\
\text { CXCL8 }\end{array}$ & $\begin{array}{l}\text { DMSO, DMF } \\
\text { ATRA, DMSO }\end{array}$ & $\begin{array}{l}{[80,86]} \\
{[86]}\end{array}$ \\
\hline Chemotaxis & $\begin{array}{l}\text { fMLF } \\
\text { CXCL8 } \\
\text { LTB4 } \\
\text { C5a }\end{array}$ & $\begin{array}{l}\text { DMSO, dbcAMP } \\
\text { ATRA, DMSO } \\
\text { RA } \\
\text { dbcAMP }\end{array}$ & $\begin{array}{l}{[81,86,87]} \\
{[86]} \\
{[87]} \\
{[88]}\end{array}$ \\
\hline ROS production & $\begin{array}{l}\text { PMA } \\
\text { fMLF } \\
\text { Opsonized zymosan }\end{array}$ & $\begin{array}{l}\text { DMSO, ATRA } \\
\text { DMSO } \\
\text { DMSO }\end{array}$ & $\begin{array}{l}{[126,127]} \\
{[126]} \\
{[127]}\end{array}$ \\
\hline NETosis & $\begin{array}{l}\text { Cls } \\
\text { PMA }\end{array}$ & $\begin{array}{l}\text { DMSO, ATRA, DMF } \\
\text { ATRA, DMF }\end{array}$ & $\begin{array}{l}{[134,|4|-\mid 43]} \\
{[142,143]}\end{array}$ \\
\hline Phagocytosis & $\begin{array}{l}\text { Saccharomyces Cerevisiae } \\
\text { Latex beads } \\
\text { Antibody-coated bacteria } \\
\text { Complement-coated bacteria }\end{array}$ & $\begin{array}{l}\text { RA } \\
\text { DMSO, RA } \\
\text { DMF } \\
\text { DMF }\end{array}$ & $\begin{array}{l}{[146]} \\
{[87]} \\
{[1|4,||15,| 47]} \\
{[148]}\end{array}$ \\
\hline
\end{tabular}

Abbreviations: ATRA, all-trans retinoic acid; C5a, complement component 5a; Cls, calcium ionophores; CXCL8, CXC motif chemokine ligand 8; dbcAMP, dibutyryl cyclic AMP; DMF, dimethylformamide; DMSO, dimethyl sulfoxide; fMLF, N-formyl-methionine-leucyl-phenylalanine; LTB4, leukotriene B4; PMA, phorbol I2-myristate I3-acetate; RA, retinoic acid; ROS, reactive oxygen species. 
surface of the neutrophils, initiating arrest, firm adhesion and transmigration through the endothelial layer. ${ }^{64}$

Apart from chemokines, three other groups of neutrophil chemoattractants have been described: lipid chemoattractants (eg, Leukotriene B4 [LTB4], which binds to Leukotriene B4 receptor 1 and 2 [BLT1 and BLT2, respectively]); peptides (eg, N-formyl-Met-Leu-Phe [fMLF], which binds to formyl peptide receptors 1 and 2 [FPR1 and FPR2, respectively]); and complement anaphylatoxins (eg, C5a, which binds to C5a receptors 1 and 2 [C5aR1 and C5aR2, respectively]). ${ }^{65}$ All chemoattractant receptors are G-protein coupled receptors (GPCRs) and converge into the same signaling pathways leading to migration.

The GPCR is coupled to a trimeric G-protein bound to GDP. Upon ligand binding, the G-protein is activated, exchanging the GDP for GTP. This leads to dissociation of the G-protein into a $G \alpha$ and a $G \beta \gamma$ subunit. Subsequently, the G $\beta \gamma$ subunit initiates two independent intracellular signaling pathways, each of which contributes to neutrophil chemotaxis. ${ }^{66}$ First, the PLC/DAG pathway leads to activation of Rap1 and consequent mobilization of integrins, which ensure firm adhesion of the neutrophil to the endothelial wall. ${ }^{67}$ Second, the PI3K pathway leads, via the generation of $\mathrm{PIP}_{3}$, to the activation of Rac and $\mathrm{Cdc} 42$, which promote the accumulation of polymerized actin (filamentous actin [F-actin]) at the leading edge of the cell. The polymerized actin accumulates at the front of the cell (leading edge) and pushes the membrane forward. ${ }^{67}$ Meanwhile, at the rear end of the cell (uropod), the Rho-activated protein ROCK activates myosin II, which binds to the actin filaments and ensures retraction of the uropod. ${ }^{68}$ To cross the endothelial layer (diapedesis), the neutrophil needs to either crawl between the cells (paracellular route) or go directly through them (transcellular route). In both cases, the neutrophils activate ICAM-
1 molecules on the surface of the endothelial cells, which either induces the formation of intracellular channels (employed in the transcellular route) or, together with the endothelial molecule VCAM-1, destabilizes VE-cadherin, a major component of adherens junctions between the endothelial cells. ${ }^{69}$

\section{Chemoattractant Receptors on dHL-60 Cells}

Upon granulocytic differentiation, HL-60 cells have been shown to upregulate receptors for fMLF, LTB4, C5a, C3a, platelet-activating factor (PAF) and $\mathrm{CXC}$ chemokines (Table 2). ${ }^{70-77}$ The levels of CXCR1 and CXCR2 have been reported to be relatively low compared to wild-type neutrophils. ${ }^{77}$

Interestingly, a study by Jacobs et al showed that the G-protein/receptor complexes for fMLF, LTB4 and C5a on DMSO-dHL-60 have a different affinity for GTP binding, resulting in different potency of the chemoattractant. The authors demonstrate that DMSO-dHL-60 cells preferentially respond to fMLF, less readily to C5a and least readily to LTB $4 .^{78}$

\section{Expression of Adhesion Molecules on HL-60 Cells}

The leukocyte-specific CD62L is virtually absent on uHL60 and only appears upon differentiation, although the expression levels do not reach those of peripheral blood neutrophils. ${ }^{82}$ By contrast, PSGL-1 is expressed on both dHL-60 and uHL-60 cells at similar levels. ${ }^{83}$ The upregulation of $\mathrm{CD} 62 \mathrm{~L}$ upon differentiation is reflected in the rolling speed of the cells: dHL-60 cells rolled significantly faster than uHL-60 cells when placed in a flow chamber coated with P-selectin. ${ }^{83}$ In addition, Sjögren et al reported that differentiation of HL-60 cells with DMSO induced the surface expression of CD11b, a component of the $\beta_{2^{-}}$ integrin Mac-1 (CD11b/CD18). ${ }^{82}$ Since dHL-60 cells do

Table 2 Chemoattractant Receptors Expressed on the Surface of Differentiated HL-60 Cells

\begin{tabular}{|l|l|l|l|}
\hline Receptor & Ligand & Differentiation Agent $^{\mathbf{a}}$ & Reference $^{-}$ \\
\hline BLT & LTB4 & DMSO, ATRA & {$[73,79]$} \\
C3aR & C3a & dbcAMP & {$[74]$} \\
C5aR & C5a & dbcAMP & {$[70,74]$} \\
CXCRI (low) & CXCL6,8 & ATRA, DMSO & {$[76]$} \\
CXCR2 (low) & CXCLI,2,3,5,6,7,8 & DMSO & {$[77]$} \\
FPR & N-formyl peptides (eg fMLF) & dbcAMP, DMF, DMSO & {$[70,71,80,8 I]$} \\
PAF receptor & PAF & DMSO & {$[75]$} \\
\hline
\end{tabular}

Note: ${ }^{a}$ Compounds that have been demonstrated to induce receptor expression on HL-60 cells.

Abbreviations: ATRA, all-trans retinoic acid; BLT, leukotriene B4 receptor; C3a, complement component 3a; C3aR, C3a receptor; C5a, complement component 5a; C5aR, C5a receptor; CXCL, CXC motif chemokine ligand; CXCR, CXC chemokine receptor; dbcAMP, dibutyryl cyclic AMP; DMF, dimethylformamide; DMSO, dimethyl sulfoxide; fMLF, N-formyl-methionine-leucyl-phenylalanine; FPR, formyl peptide receptor; PAF, platelet-activating factor. 
not have CD11b-containing specific granules, the authors suggest that the CD11b must be coming from a different intracellular source. ${ }^{84}$ In addition, the same authors showed that while DMSO caused a strong upregulation of CD11b and CD62L, the effect of RA was much more limited, which was reflected in the reduced migratory capacity of RA-dHL-60. ${ }^{82}$ Finally, the expression of the $\beta_{2}$-integrin CD11c/CD18 is slightly upregulated by differentiation with DMSO or RA, although the surface protein expression remains low. ${ }^{85}$

\section{Chemotaxis Function in dHL-60 Cells}

It has been demonstrated that dHL-60 cells form actin filaments, visibly polarize and directionally migrate in response to $\mathrm{fMLF}$, LTB4, C5a and CXCL8, indicating that pathways downstream of the receptors are mostly intact. $^{72,80,86-89}$ To confirm this, Hauert et al specifically verified that the PI3K and Rho pathways in dHL-60 cells are identical to those found in peripheral blood neutrophils. ${ }^{89}$ Of note, a reduced response towards fMLF has been reported in ATRA-dHL-60. ${ }^{79,86,87,90}$

Despite the chemotaxis pathways being fully functional in dHL-60 cells, most studies report that the average response is slightly lower than that of peripheral blood neutrophils, probably due to reduced expression levels of the receptors. ${ }^{77,80,89}$

Many studies report the inability of undifferentiated HL-60 cells to migrate in response to chemotactic stimuli. ${ }^{80,82,89}$ While this is perfectly explainable by low expression of chemoattractant receptors and adhesion molecules (vide supra), another study has shown that HL-60 synthesize large amounts of actin upon differentiation. ${ }^{91}$ Perhaps the actin content in undifferentiated HL-60 cells is too low for efficient cell polarization and movement, contributing to their inability to transmigrate. This hypothesis is supported by the findings of Prossnitz et al, who transfected uHL-60 cells with FPR and observed increased but insufficient actin polymerization in response to fMLF stimulation. By contrast, other responses to fMLF, such as mobilization of intracellular calcium, were intact in this study. ${ }^{92}$

\section{Transgenic HL-60-Derived Sublines for Chemotaxis Studies}

Certain limitations of dHL-60 cells (eg, low receptor expression or affinity) can be overcome by creating transgenic sublines. For example, Kikuchi-Ueda et al established an HL-60 cell line overexpressing CXCR1. ${ }^{76}$ When differentiated with ATRA, these cells showed a fourfold increase in chemotaxis towards CXCL8 as compared to conventional dHL-60 cells. Similarly, HL-60 cells overexpressing CXCR2 and FPR have been created. ${ }^{77,92}$ These sublines can be useful for studying receptor signaling in more detail, or for testing selective receptor inhibitors. For example, targeting CXCR2 might alleviate lung injury induced by an excessive neutrophil influx. ${ }^{93}$

Recently, Garner et al created an HL-60-derived cell line which expressed green fluorescent protein (GFP)labeled $\beta$-actin, the most abundant actin isoform in neutrophils. $^{94}$ When differentiated with DMSO, this novel cell line has been shown to migrate towards fMLF with an efficiency approaching that of wild-type neutrophils, making it an interesting model to study actin dynamics during neutrophil chemotaxis.

\section{HL-60 Cells for the Study of Phagocytosis Phagocytosis in Neutrophils - An Overview}

Phagocytosis is a multi-step process that results in the engulfment of particles by a cell; to achieve this, distinct cellular mechanisms are required. First, the pathogen is recognized by a receptor on the surface of the neutrophil. This can be either an opsonic or a non-opsonic receptor. An example of non-opsonic receptors are C-type lectins, such as Dectin-1 (which recognizes $\beta$-glucan on fungal cells and yeast polysaccharide) and Mincle (which recognizes the trehalose dimycolate [TDM] motif on mycobacterial cell walls). ${ }^{95}$ To recognize opsonized particles, neutrophils employ either Fc $\gamma$ receptors (Fc $\gamma R s$ ) (eg, CD32 or CD16), which bind the constant region of IgG antibodies, or complement receptors (eg, CR3 [CD11b/ CD18] or CR4 [CD11c/CD18], both of which recognize proteolytic fragments of $\mathrm{C} 3 \mathrm{~b}$ ). ${ }^{96,97}$ Upon binding, the receptors initiate intracellular signaling cascades, which differ for each receptor but have a similar outcome. Activation of small GTPases (eg, Rac2 in case of Fc $\gamma$ Rs or Rho in case of complement receptors) ultimately results in actin remodeling, leading to the uptake of the bound particle in a phagosome; this can either or not be mediated by the formation of pseudopodia. ${ }^{95}$ In addition, the actin remodeling translocates azurophilic and specific granules closer to the phagosome. At the same time, an increase in intracellular calcium concentration induces the formation of pores in the phagosome, allowing fusion between the phagosome and the granules to take place. ${ }^{98}$ This fusion leads to exposure of the pathogen to antimicrobial peptides (eg, defensins) and proteases (eg, NE); in case of specific 
granules, this process is dependent on free cytosolic calcium. Finally, the recruitment of the NADPH oxidase complex to the phagosome enhances pathogen killing through generation of different reactive oxygen species (ROS), including hydrogen peroxide and hypochlorous acid. ${ }^{99}$ Priming of neutrophils (eg, with TNF- $\alpha$ ) has been shown to improve phagocytosis efficiency by increasing the number of phagocytic receptors on the plasma membrane and enhancing their affinity towards their ligand, as well as stimulating degranulation and superoxide production. $^{100}$

\section{Phagocytic Receptors on (d)HL-60 Cells}

In contrast to chemoattractant receptors, some phagocytic receptors are expressed on undifferentiated HL-60 cells, albeit at low levels (Table 3). Expression of C1qRp, CR1, CR3, CR4 and FcyRII increases upon differentiation, although the receptor levels usually do not reach those of peripheral blood neutrophils. $^{85,101}$

\section{Phagocytosis Function in HL-60 Cells}

Undifferentiated HL-60 cells have very low phagocytic ability, if any. uHL-60 were shown not to have cytotoxic activity towards opsonized chicken erythrocyte target cells; stimulation with IFN- $\gamma$ induced some cell killing but this was not nearly as effective as compared to peripheral blood neutrophils. ${ }^{107}$ Upon differentiation, HL-60 cells have been shown to effectively phagocytose various particles, including latex beads, Escherichia coli, opsonized yeast and opsonized bacteria. ${ }^{33,87,111-116}$ Lerm et al investigated the phagocytic pathway in more detail by constitutively expressing Cdc42 in dHL-60 cells. Cdc42 is a small GTPase which has a role in actin polymerization; constitutively activated $\mathrm{Cdc} 42$ led to polarization of the cells in absence of stimulus and induced accumulation of actin filaments around phagosomes, preventing their fusion with azurophilic granules. ${ }^{117}$ Another group demonstrated that inhibition of this fusion can be employed by Streptococcus pyogenes which can survive inside both dHL-60 cells and peripheral blood neutrophils. ${ }^{84}$

While the pathogen uptake mechanisms in dHL-60 cells seem to be mostly functional, the intracellular killing is much less efficient. ${ }^{112,116,118,119}$ This could be explained by the fact that HL-60 cells lack specific granules and do not acquire them upon differentiation. ${ }^{84}$

\section{HL-60 Cells to Study Neutrophil Respiratory Burst}

\section{Respiratory Burst in Neutrophils - An Overview}

Another weapon in the arsenal of neutrophils is the respiratory burst, characterized by high production of ROS. These are highly reactive derivatives of oxygen molecules, capable of damaging pathogens both inside and outside the cell. Central to the ROS production is the

Table 3 Expression of Phagocytic Receptors on Undifferentiated (uHL-60) and Differentiated (dHL-60) Cells

\begin{tabular}{|c|c|c|c|c|}
\hline Receptor & Examples of Ligands & Expression on uHL-60 & Expression on dHL-60 & References \\
\hline $\mathrm{ClqRp}$ & $\mathrm{Clq} ?^{\mathrm{a}}$ & - & $\begin{array}{l}\text { DMSO: - or + } \\
\text { RA: - }\end{array}$ & {$[101,102]$} \\
\hline CRI (CD35) & $\mathrm{Clq}, \mathrm{C} 3 \mathrm{~b}, \mathrm{C} 4 \mathrm{~b}, \mathrm{MBL}$ & - & $\begin{array}{l}\text { DMSO: ++ } \\
\text { RA: }++\end{array}$ & {$[103-105]$} \\
\hline CR3 (CDIIb/CDI8) & $\mathrm{iC} 3 \mathrm{~b}$ & + & $\begin{array}{l}\text { DMSO: ++ } \\
\text { RA: ++ }\end{array}$ & {$[82,101,102,104,106]$} \\
\hline CR4 (CDII /CDI8) & $\mathrm{iC3b}$ & - & $\begin{array}{l}\text { DMSO: + } \\
\text { RA: + }\end{array}$ & [85] \\
\hline Fc $\gamma R I$ & $\lg \mathrm{I}, \lg \mathrm{g} 3, \lg G 4, \lg \mathrm{G}$ immune complexes & + or ++ & $\begin{array}{l}\text { DMSO: ++ } \\
\text { ATRA: ++ } \\
\text { DMF: ++ }\end{array}$ & {$[107-109]$} \\
\hline Fc $\gamma$ RII & IgG immune complexes & + or ++ & RA: ++ & {$[107,108,110]$} \\
\hline Fc $\gamma R$ RIII & IgG3, IgG immune complexes & - & unknown & {$[107,108]$} \\
\hline
\end{tabular}

Note: ${ }^{a}$ The question mark indicates that the affinity of $\mathrm{ClqRp}$ for $\mathrm{Clq}$ is still under debate.

Abbreviations: ATRA, all-trans retinoic acid; Clq, complement component Iq; ClqRp, Clq receptor; C3b, complement component 3b; C4b, complement component 4b; CR, complement receptor; DMF, dimethylformamide; DMSO, dimethyl sulfoxide; Fc $\gamma$ R, Fc $\gamma$ receptor; lgG, immunoglobulin G; RA, retinoic acid; -, no expression; +, low expression; ++, moderate to high expression. 
NADPH oxidase complex, which is called NOX2 in neutrophils. ${ }^{120}$ NOX2 consists of a catalytic core (flavocytochrome $b_{558}$ or $c y t b_{558}$ ) and a number of proteins which are required for its activation. $C y t b_{558}$ resides in the membrane surrounding the cell or the specific granules, and consists of the $\mathrm{p} 22^{\text {phox }}\left(\alpha\right.$ subunit) and the gp91 ${ }^{\text {phox }}(\beta$ subunit). $\mathrm{p} 40^{\text {phox }}, \mathrm{p} 47^{\text {phox }}$ and $\mathrm{p} 67^{\text {phox }}$ together form a complex that is located in the cytosol under resting conditions. Upon activation of the neutrophil, $\mathrm{p} 47^{\text {phox }}$ is phosphorylated at multiple sites by protein kinases, such as PKC, p38 MAPK or p21-activated kinase (PAK). ${ }^{121}$ This leads to the translocation of the $\mathrm{p} 40^{\mathrm{phox}} / \mathrm{p} 47^{\text {phox }}$ p $67^{\text {phox }}$ complex to the membrane, where it associates with cyt $b_{558}$ to form a NOX2 complex. Additional binding of the small GTPase Racl improves the binding between the NOX2 components necessary for activation. $^{120}$ The NADPH oxidase can then produce superoxide anions $\left(\mathrm{O}_{2}{ }^{-}\right)$by transferring electrons from the cytosolic NADPH to oxygen molecules on the other side of the membrane. The superoxide dismutates into hydrogen peroxide $\left(\mathrm{H}_{2} \mathrm{O}_{2}\right)$, after which the enzyme MPO converts it to other oxygen species, such as hypochlorous acid. $^{122}$ MPO is produced in large quantities at the promyelocytic stage of neutrophil development, upon which it is stored in azurophilic granules until neutrophil activation; in terminally differentiated cells, MPO mRNA is usually not detectable. ${ }^{123}$

\section{Respiratory Burst in dHL-60 Cells}

Undifferentiated HL-60 cells have been shown to express both a functional NADPH oxidase and MPO, and thus to be capable of ROS production; however, the expression of gp91 9 phox, $\mathrm{p} 47^{\text {phox }}$ and $\mathrm{p} 67^{\text {phox }}$ RNA was found to be considerably higher in dHL-60 cells. $^{123,124}$ Interestingly, the generation of ROS has been found to be critically important for the survival of the cells, as the addition of antioxidants significantly reduced their viability. ${ }^{125}$ Stimulation of uHL-60 cells with compounds that normally induce ROS production (eg, phorbol 12-myristate 13-acetate [PMA], a direct activator of $\mathrm{PKC}$ ) did not trigger an increased ROS production by uHL-60 cells. ${ }^{125,126}$ In contrast, dHL-60 cells responded to PMA and fMLF stimulation with a prompt peak in ROS production, accompanied by a decrease in mRNA expression of MPO. ${ }^{126}$ The superoxide production by DMSO-dHL-60 cells in response to PMA and opsonized zymosan was comparable to that of peripheral blood neutrophils, but the total amount of radicals was lower in dHL-60 cells, possibly indicating a reduced function of proteins downstream of the NOX2 complex, or an increased activity of anti-oxidative enzymes. $^{127}$ Of note, several studies reported that ATRA-dHL-60 produce a less powerful respiratory burst in response to fMLF as compared to DMSO-dHL $-60 .^{79,90}$ This is consistent with the observation that ATRA only induces the expression of fMLF receptors with a low ligand affinity. ${ }^{79}$

Several studies used RNA interference for better characterization of pathways involved in the respiratory burst. Thus, depletion of PKC $\beta$ in dHL-60 cells resulted in decreased translocation of $\mathrm{p} 47^{\text {phox }}$ to the plasma membrane and subsequent reduction in superoxide production, whereas inhibition of $\mathrm{PKC} \delta$ reduced superoxide production without affecting $\mathrm{p} 47^{\text {phox }}$ location. ${ }^{128,129}$ In addition, dHL60 were shown to be sensitive to priming with TNF- $\alpha .{ }^{130}$

Finally, the reader is referred to an excellent paper by Seitz et al for a comparison of methods best suited to detect the respiratory burst in dHL-60 cells. ${ }^{131}$

\section{HL-60 Cells to Study Neutrophil Extracellular Traps NETosis - An Overview}

NETosis, ie, cell death featuring expulsion of neutrophil extracellular traps (NETs), is a defense mechanism in which the neutrophil releases its DNA as decondensed chromatin mixed with histones and granule proteins. Currently, there is still much debate on the origin of the expulsed DNA (ie, nuclear or mitochondrial) as well as whether the cell releasing a NET necessarily dies (suicidal NETosis) or remains viable and capable of exerting other functions in antimicrobial defense (vital NETosis). ${ }^{132}$ However, most studies agree that there are three central players in the process of NETosis: ROS, NE and protein arginase deiminase 4 (PAD4). ROS are produced upon assembly and activation of the NOX2 complex; during NETosis, they cause damage to the nuclear and granular membranes, allowing contact between nuclear and cytoplasmic content. NE and granular proteases, empowered by MPO, cleave histones to facilitate chromatin decondensation. PAD4 is a calcium-dependent enzyme which promotes chromatin decondensation by citrullinating the histones, thereby altering their charge and weakening their interaction with DNA. ${ }^{133}$ The extended decondensation of chromatin leads to the rupture of the plasma 
membrane and the release of NETs into the extracellular space. $^{134}$

Both physiological and artificial stimuli have been demonstrated to induce NETosis. Physiological stimuli include the bacterial lipopolysaccharide (LPS), CXCL8 and monosodium urate (MSU) crystals. ${ }^{135,136}$ Two of the artificial stimuli commonly used in NETosis research, are PMA and calcium ionophores (CIs). ${ }^{137}$ PMA is a molecule that freely crosses the plasma membrane and directly activates PKC which on its turn promotes NOX2 activation. ${ }^{138} \mathrm{CIs}$ are a group of molecules which trigger calcium release into the cytoplasm from the endoplasmic reticulum stores. ${ }^{139}$

\section{NETosis in dHL-60 Cells}

The first study into NET formation by HL-60 cells was performed in 2008 by Neeli et al, who demonstrated histone citrullination in ATRA-dHL-60 cells stimulated with a wide range of stimuli (eg, CIs, TNF- $\alpha$, fMLF, LPS). The histone citrullination was completely independent of apoptosis, as no caspase activation was detected; vice versa, apoptosis-inducing compounds did not induce citrullination of histones. A comparison between dHL-60 and peripheral blood neutrophils showed that the extent and timespan of the histone citrullination were very similar between the two, but that dHL-60 cells were only triggered by much higher concentrations of the stimuli. ${ }^{140}$ The data of Neeli et al were complemented by a later study, which showed that the expression of PAD4 increased upon differentiation of HL-60 cells with DMSO, and that stimulation with a CI led to expulsion of NETs. ${ }^{141}$ HL-60 cells deficient in PAD4 showed a delay in DNA decondensation and largely failed to expulse NETs due to defects in plasma membrane rupture. $^{134}$ Interestingly, NETs produced by dHL-60 cells in response to PMA and a CI had a different morphology from those produced by peripheral blood neutrophils: the strands of DNA were much shorter and remained close to the cells. ${ }^{142}$ Another study found that both DMSO- and ATRA-dHL-60 cells were capable of producing NETs in response to Staphylococcus aureus, albeit much less efficient than peripheral blood neutrophils. ${ }^{119}$

An extensive study by Manda-Handzlik et al compared the NET-forming capacity of HL-60 cells after differentiation with various compounds (DMSO, ATRA, DMF). Surprisingly, the results indicated differences between the differentiation agents: ATRA-dHL-60 cells only released
NETs in response to PMA; DMSO-dHL-60 cells only in response to a CI, and DMF-dHL-60 cells in response to both. ${ }^{142}$ However, these data have been contradicted by other studies, which demonstrated that ATRA-dHL-60 cells can also react to CIs and DMSO-dHL-60 cells also to PMA. ${ }^{143,144}$

Importantly, Takishita et al found that the DNA expulsed by dHL-60 cells was genomic rather than mitochondrial, as removal of mitochondrial DNA had no effect on PMA-induced NET release. ${ }^{143}$

\section{HL-60 Cells to Study Immunosuppressive Function of Neutrophils}

Recently, Zhang et al described the generation of MDSClike neutrophils from HL-60 cells. ${ }^{145}$ To this end, the cells were differentiated with DMSO and treated with a combination of granulocyte-monocyte colonystimulating factor (GM-CSF) and IL-6. The resulting cells suppressed cytokine production and apoptosis of $\mathrm{T}$ lymphocytes. In addition, MDSC-like dHL-60 cells had a gene expression signature that was very similar to that of natural MDSC cells. This is a promising model for studying neutrophil immunosuppressive function, eg, in cancer and autoimmunity research.

\section{Cell Lines Less Commonly Used as Neutrophil Model PLB-985 Cell Line}

PLB-985 cells were introduced in 1987 as a novel cell line; however, later research revealed PLB-985 to be a subline of HL-60, having nearly identical DNA and very similar gene expression. ${ }^{149-151}$

\section{NB4 Cell Line}

NB4 is a cell line originally established in 1991 from a female patient with relapsed acute promyelocytic leukemia. It is cultured in RPMI-1640 medium with serum supplementation, but without any other additives. ${ }^{152}$ The cell line has mainly attracted attention as a model to study cell differentiation in leukemia, but NB4 cells treated with ATRA display many features of terminally differentiated neutrophils and are therefore perfectly suitable for studying neutrophil function as well. ${ }^{152,153}$ In contrast to HL-60 cells, NB4 cells express a fusion protein that is formed between the retinoid receptor RAR $\alpha$ and the tumorsuppressor protein promyelocytic leukemia (PML). ${ }^{154}$ This fusion protein, PML-RAR $\alpha$, binds to transcriptional 
targets of ATRA but does not initiate transcription. Addition of substantial amounts of ATRA displaces the fusion protein from the DNA and allows normal transcription of ATRA target genes. ${ }^{155}$ Differentiated NB4 cells are capable of producing ROS and possess functional azurophilic granules but do not contain specific or gelatinase granules; while the presence of both lactoferrin and MMP9 has been demonstrated, they are not contained in granules. ${ }^{153,156-158}$ A study by Barber et al compared the changes in expression of CD markers between NB4 and HL-60 cells upon ATRA differentiation (Table 4). ${ }^{159}$ The authors suggest that the difference in marker expression can be explained by the actions of PML-RAR $\alpha$ in NB4 cells, whose function may differ from wildtype $\operatorname{RAR} \alpha$ even after ATRA binding.

\section{Kasumi-I Cell Line}

Kasumi-1 is a cell line established in 1991 from a male pediatric patient with acute myeloblastic leukemia. Kasumi-1 cells proliferate with a doubling time of $40-45$ hours, but require the presence of stimulatory cytokines (eg, granulocyte colony-stimulating factor [G-CSF], IL-6) in the culture medium. ${ }^{160}$ Whereas Kasumi-1 have mostly been of interest for leukemia rather than neutrophil research, recently Schoenherr et al found that silencing of the RUNX1-ETO oncogene induced features of neutrophil differentiation, including reduced proliferation and

Table 4 Changes in Expression of CD Markers on HL-60 and NB4 Cells Upon ATRA Differentiation ${ }^{\mathrm{a}}$, as Described by Barber et al ${ }^{159}$

\begin{tabular}{|l|l|l|l|l|l|}
\hline Marker & HL-60 & NB4 & Marker & HL-60 & NB4 \\
\hline CD9 & - & $\downarrow$ & CD45 & $\uparrow$ & - \\
CDIIa & - & $\uparrow$ & CD45RO & $\uparrow$ & $\downarrow$ \\
CDIIb & $\uparrow$ & $\uparrow$ & CD53 & $\uparrow$ & $\uparrow$ \\
CDIIl & $\uparrow$ & $\uparrow$ & CD54 & $\uparrow$ & $\uparrow$ \\
CDI3 & - & $\downarrow$ & CD64 & $\uparrow$ & $\uparrow$ \\
CDI4 & - & $\uparrow$ & CD65 & - & $\uparrow$ \\
CD29 & $\downarrow$ & $\downarrow$ & CD66c & $\uparrow$ & $\uparrow$ \\
CD3I & - & $\downarrow$ & CD95 & $\downarrow$ & - \\
CD32 & - & $\uparrow$ & CDII7 & $\downarrow$ & - \\
CD36 & $\uparrow$ & - & CDI26 & - & $\uparrow$ \\
CD38 & $\uparrow$ & $\downarrow$ & CDI38 & - & $\uparrow$ \\
CD43 & $\uparrow$ & $\downarrow$ & TCR $/ \beta$ & - & $\uparrow$ \\
CD44 & $\downarrow$ & $\downarrow$ & & & \\
\hline
\end{tabular}

Notes: ${ }^{a}$ The table only contains markers that were detectable on undifferentiated cells. A change is defined as an increase or reduction of two-fold or more.

Abbreviations: $C D$, cluster of differentiation; TCR, T cell receptor; -, no change in expression; $\uparrow$, expression increased after differentiation; $\downarrow$, expression reduced after differentiation. higher expression of $\mathrm{NE}$ and cathepsin $\mathrm{G}$, markers of azurophilic granules. ${ }^{161}$ As Kasumi-1 cells are in a very early stage of myeloid differentiation, this model might provide research opportunities for studying (early) neutrophil development.

\section{Induced Pluripotent Stem Cells as a Model for Human Neutrophils}

Another emerging alternative for peripheral blood neutrophils is the use of induced pluripotent stem cells (iPSCs). iPSCs can be derived from any somatic cell by "erasing" its differentiation memory and thus reverting it to a pluripotent state. This can be done by the addition of several transcription factors crucial for maintaining the pluripotent phenotype. ${ }^{162}$ A commonly used combination of transcription factors is OCT4, SOX2, KLF4 and c-MYC. These factors can be added to terminally differentiated cells, eg, through plasmid transfection or retroviral transduction. ${ }^{162}$ Other reprogramming factors are used less often, and are described in detail by Xiao et $\mathrm{al}^{163}$.

Upon their generation, iPSCs can be expanded and/or cryopreserved. ${ }^{164}$ Subsequently, the pluripotent stem cells can be differentiated into a whole range of cell types, including hematopoietic cells and specifically neutrophils. ${ }^{165,166}$ Differentiation is performed by culturing the iPSCs in the presence of a combination of specific growth factors and cytokines, including stem cell factor (SCF), IL-6 and G-CSF. A detailed protocol for neutrophilic differentiation of iPSCs has been described by Sweeney et al. ${ }^{167}$ A simpler method for the generation of iPSC-derived neutrophils has been proposed by Lachmann et al in 2015; this protocol relies on the addition of only two cytokines: IL-3 and G-CSF. ${ }^{168}$ However, neutrophils obtained with this method have been shown to be less fully differentiated and less capable of ROS production and bacterial killing. ${ }^{168,169}$

The use of iPSCs has both advantages and disadvantages compared to other models for human neutrophils. One obvious advantage is the close resemblance of iPSCderived neutrophils to neutrophils found in peripheral blood, as shown by the presence of all neutrophil-specific granules. In addition, ROS production, phagocytic activity and chemotaxis capacity of iPSCs are very similar to that of peripheral blood neutrophils. ${ }^{166}$ Another advantage is the possibility to create disease-specific cell lines by generating iPSCs from patients with different mutations. This has been elegantly illustrated by Brault et al, who 
established iPSC cell lines from patients with chronic granulomatous disease (CGD), a genetic disorder characterized by dysfunctional neutrophils which are unable to produce ROS. ${ }^{170}$

Disadvantages associated with the use of iPSCs for neutrophil research are mostly practical. The generation of iPSC-derived neutrophils takes at least a month even if the iPSCs themselves are already available. ${ }^{167}$ In addition, the process is expensive due to the large amounts of cytokines required for the differentiation. Therefore, extra care is advised when planning the experiments.

\section{Neutrophil Function in vitro - Effect of Environmental Factors}

\section{Glucose Concentration}

Neutrophils can only be kept alive within a short time frame, but different buffer solutions are suitable, ranging from phosphate-buffered saline (PBS) to glucose-supplemented culturing media, such as RPMI-1640 (glucose concentration $11.1 \mathrm{mM}$ ) or DMEM (glucose concentration 5.6 or 25 $\mathrm{mM}) .{ }^{171,172}$ For comparison, the fasting blood glucose levels in healthy individuals range from 3.5 to $5.5 \mathrm{mM} .{ }^{173}$ Studies addressing the effect of glucose on neutrophil function have shown that pre-incubation of neutrophils in medium containing more than $5 \mathrm{mM}$ glucose led to reduced chemotaxis, phagocytosis and bactericidal capacity. ${ }^{174,175}$ Above 11.1 $\mathrm{mM}$, there was also a reduction in respiratory burst, actin polymerization and neutrophil adhesiveness. ${ }^{174,176,177}$ Menegazzo et al reported that at $25 \mathrm{mM}$, glucose promoted the formation of NETs; however, this was contradicted by the group of Joshi et al, who stated that high glucose actually impaired NET formation. ${ }^{178,179}$

Of note, reduced chemotaxis and ROS production were also reported when neutrophils were pre-incubated in glucose-free medium, indicating that there is an optimal glucose concentration at which neutrophil function is maximal. ${ }^{175,180}$ Interestingly, glucose had no effect on neutrophil viability. ${ }^{174,180}$

\section{$\mathrm{pH}$}

In healthy individuals, the $\mathrm{pH}$ of blood lies between 7.35 and 7.45, but at sites of inflammation, the $\mathrm{pH}$ often drops to 7.0 or lower. ${ }^{181,182}$ Low $\mathrm{pH}$ can greatly influence the function of neutrophils. In a more acidic environment, neutrophils will produce less ROS and release fewer NETs. ${ }^{183-186}$ Neutrophil chemotaxis is optimal around $\mathrm{pH} 7.2-7.5$ and is inhibited by $\mathrm{pH}$ values outside that range. ${ }^{187,188}$ In addition, $\mathrm{pH}$ values under 7.2 have been shown to inhibit phagocytosis. ${ }^{189}$ In contrast, other neutrophil functions, such as release of specific granules and adhesion to endothelium, can be promoted in an acidic environment. ${ }^{189,190}$ In addition, Geffner et al observed an increased cytotoxic capacity of neutrophils under low $\mathrm{pH}$, despite earlier reports of an inhibited respiratory burst in acidic conditions. ${ }^{191}$ The authors hypothesize that while the production of some ROS species is inhibited, the production of others may be increased, contributing to neutrophil cytotoxicity; however, more research is needed to test this hypothesis.

\section{Oxygen Levels}

Atmospheric oxygen tension equals $21 \mathrm{kPa}$, but in the circulation this value drops to $5-13 \mathrm{kPa} .{ }^{192}$ In tissues, especially during inflammation, hypoxia can occur as the oxygen tension can drop below $2.5 \mathrm{kPa} .{ }^{192}$ Examples of factors that contribute to this low oxygen tension are high oxygen consumption by neutrophils (fueling the respiratory burst) and depletion of oxygen by the invading pathogen. ${ }^{193,194}$ Thus, in the human body, neutrophils often exert their function under hypoxia. This is important to realize, since most experiments on human neutrophils are routinely performed under atmospheric oxygen pressure, and the results of these experiments may not necessarily reflect the situation in vivo.

Hypoxia has two major effects on neutrophil function. Firstly, the low availability of oxygen molecules restricts the production of reactive oxygen species. ${ }^{195-200}$ Depending on the extent of hypoxia, this can have an inhibitory effect on the formation of NETs and bactericidal activity. ${ }^{201-203}$ Vice versa, exposing neutrophils to hyperoxia leads to increased respiratory burst. ${ }^{204}$

Secondly, hypoxia significantly delays neutrophil apoptosis, a feature which is dependent on Hypoxia-Inducible Factor $1 \alpha$ (HIF-1 $\alpha) .{ }^{195-200}$ HIF-1 $\alpha$ forms a heterodimer with HIF-1 $\beta$, constituting the transcription factor HIF-1. ${ }^{205}$ Under normoxic conditions, the proline residues of the HIF$1 \alpha$ protein are hydroxylated by prolyl hydroxylases. ${ }^{206}$ This modification promotes the interaction of HIF- $1 \alpha$ with the von Hippel-Lindau tumor-suppressor protein (VHL), inducing ubiquitylation and consequent proteasomal degradation of HIF-1 $\alpha^{207}$ As prolyl hydroxylases require the presence of oxygen as a co-factor, their function is inhibited under hypoxic conditions, resulting in the preservation of HIF$1 \alpha{ }^{208}$ HIF- $1 \alpha$ can then migrate to the nucleus, associate with HIF-1 $\beta$ and initiate the transcription of genes involved 
in various processes, including glycolysis, angiogenesis and cell migration. ${ }^{209-211}$ It has been suggested that HIF-1 $\alpha$ inhibits neutrophil apoptosis by upregulating NF- $\mathrm{\kappa B}$ signaling, which can stimulate the transcription of anti-apoptotic factors. ${ }^{199,212}$

In addition to these two hypoxia-driven effects, a few studies have shown that low oxygen tension stimulates degranulation, which was found to be independent of de novo protein synthesis. ${ }^{202,213}$

Most studies found no effect of hypoxia on the expression of surface receptors, including receptors for CXCL8, fMLF and GM-CSF, and very little effect on the release of inflammatory mediators, such as CXCL8, vascular-endothelial growth factor (VEGF), IL-17 and IL-6. ${ }^{195,203,214-217}$ In addition, separate studies have suggested that hypoxia might promote phagocytosis and render neutrophils less responsive to glucocorticoids and inflammatory mediators such as TNF$\alpha$ and CXCL8, the latter being linked to dysfunction of the PLC/DAG signaling pathway downstream of the GPCR receptor. ${ }^{215,218,219}$ As the PLC/DAG pathway is involved in the activation of integrins (vide supra), it is not surprising that some studies report an inhibitory effect of hypoxia on the upregulation of $\mathrm{CD} 1 \mathrm{~b} / \mathrm{CD} 18$ and neutrophil migration. ${ }^{220,221}$ Another study reports no difference in chemotaxis between neutrophils under normoxic and hypoxic conditions. $^{203}$

\section{Temperature}

While normal body temperature is around $37^{\circ} \mathrm{C}$, purification of neutrophils from peripheral blood is commonly done at room temperature. It is highly advisable not to perform
Table 6 Effect of Environmental Factors on Neutrophil Function

\begin{tabular}{|l|l|l|l|l|}
\hline $\begin{array}{l}\text { Neutrophil } \\
\text { Function }\end{array}$ & $\begin{array}{l}\text { High } \\
\text { Glucose }\end{array}$ & $\begin{array}{l}\text { Low } \\
\text { pH }\end{array}$ & Hypoxia & $\begin{array}{l}\text { Low } \\
\text { Temperature }\end{array}$ \\
\hline Chemotaxis & $\downarrow$ & $\downarrow$ & - & $\downarrow$ \\
Phagocytosis & $\downarrow$ & $\downarrow$ & $\uparrow$ & $\downarrow$ \\
ROS production & $\downarrow$ & $\downarrow / \uparrow$ & $\downarrow$ & $\downarrow$ \\
NETosis & $\downarrow / \uparrow$ & $\downarrow$ & $\downarrow$ & $?$ \\
Bacterial killing & $\downarrow$ & $\uparrow$ & $\downarrow$ & $\downarrow$ \\
Degranulation & $?$ & $\uparrow$ & $\uparrow$ & $?$ \\
Survival & - & $?$ & $\uparrow$ & $?$ \\
\hline
\end{tabular}

Abbreviations: ROS, reactive oxygen species; $\uparrow$, function enhanced by environmental factor; $\downarrow$, function inhibited by environmental factor; -, no change in function; ?, change in function unknown; $\downarrow / \uparrow$, contradictory results reported.

functional tests at room temperature, as neutrophil phagocytosis, bacterial killing, chemotaxis, adhesion and ROS production are all significantly decreased at room temperature as compared to $37^{\circ} \mathrm{C} .{ }^{184,187,222-227}$ In addition, it has been demonstrated that several receptors and proton channels have a reduced activity at room temperature. ${ }^{228-231}$ Reassuringly, re-warming the cells to $37^{\circ} \mathrm{C}$ after incubating them at room temperature or even at $4{ }^{\circ} \mathrm{C}$ has been shown to restore neutrophil functionality. ${ }^{227,232}$

At inflammatory sites, the temperature can be higher than $37^{\circ} \mathrm{C}$; therefore, the functionality of neutrophils at higher temperatures might also be of interest. ${ }^{233}$ The majority of studies show that neutrophils are in general less responsive to activating stimuli at temperatures above $41^{\circ} \mathrm{C} .222-224,234$

\section{Concluding Remarks}

Neutrophils are an essential part of the innate immune system, and since 1979 several granulocytic cell lines

Table 5 Advantages and Limitations of Different Cell Models for Neutrophil Research

\begin{tabular}{|l|l|l|}
\hline Cell Model & Advantages & Limitations \\
\hline HL-60 & $\begin{array}{l}\text { - Most commonly used, many protocols available } \\
\text { - Suitable for genetic editing } \\
- \text { NETosis described } \\
- \text { Easy to culture } \\
- \text { Immunosuppressive differentiation described }\end{array}$ & $\begin{array}{l}\text { - Differentiation mechanism } \\
\text { not entirely clear } \\
- \text { Bacterial killing inefficient } \\
- \text { No specific/gelatinase granules }\end{array}$ \\
\hline PLB-985* & Same as HL-60 & Same as HL-60 \\
\hline NB4 & - Clear differentiation mechanism & - No specific/gelatinase granules \\
& - Easy to culture & - Few protocols available \\
\hline Kasumi-I & - Suitable for studying early neutrophil differentiation & $\begin{array}{l}\text { - Few protocols available } \\
\text { - Expensive to culture }\end{array}$ \\
\hline Induced pluripotent stem cells & - Closely resembling wildtype neutrophils & $\begin{array}{l}\text { - Expensive to culture } \\
\text { - Protocol time-consuming }\end{array}$ \\
\hline
\end{tabular}

Note: *Subline of HL-60 cells. 
have been established and characterized. Especially the HL-60 cell line has received attention over the past decades. While many functional assays have been performed with differentiated HL-60 cells, no consensus has so far been reached on which differentiation agent produces cells that are phenotypically and functionally closest to neutrophils. Perhaps future research will shed more light on this, as well as provide a more thorough comparison between HL-60 and other granulocytic cell lines. Of course, cell lines provide an alternative for the isolation of fresh neutrophils from blood and can be easily transfected, but cannot completely replace those cells. Novel findings will always have to be confirmed in final experiments with the primary cells. A summary of the advantages and limitations of different cell lines is displayed in Table 5.

Induced pluripotent cell lines provide another alternative for the use of donor neutrophils. Although lengthy and expensive for now, the procedure for creating iPSCderived neutrophils will hopefully become simpler in the future, allowing for a model highly resembling human neutrophils from peripheral blood.

Environmental factors, such as temperature, $\mathrm{pH}$ and oxygen and glucose levels, have proven to have a strong influence on the function of neutrophils isolated from the blood. Variations in these factors are not only important for laboratory work, but are also found in physiological conditions, eg, during inflammation. Table 6 summarizes the effect of changes in environment on neutrophil function. Depending on the context of the research, these factors can be adjusted to create an environment as close to the human body as possible.

\section{Abbreviations}

ATRA, All-trans retinoic acid; BLT, Leukotriene B4 receptor; C1q, Complement component 1q; C1qRp, C1q receptor; C3a, Complement component 3a; C3aR, C3a receptor; C5a, Complement component 5a; C5aR, C5a receptor; CD, Cluster of differentiation; $\mathrm{Cdc} 42$, Cell division control protein 42 homolog; CGD, Chronic granulomatous disease; CI, Calcium ionophore; $\mathrm{CR}$, Complement receptor; $\mathrm{CXCL}$, CXC motif chemokine ligand; CXCR, CXC chemokine receptor; Cyt b558, Flavocytochrome b558; DAG, Diacylglycerol; dbcAMP, Dibutyryl cyclic AMP; DMEM, Dulbecco's modified Eagle's medium; DMF, Dimethylformamide; DMSO, Dimethyl sulfoxide; Fc $\gamma$ R, Fc $\gamma$ receptor; fMLF, N-formyl-Methionine-Leucyl-Phenylalanine; FPR, Formyl peptide receptor; GAG, Glycosaminoglycan; G-CSF, Granulocyte colony-stimulating factor; GDP,
Guanosine diphosphate; GFP, Green fluorescent protein; GMCSF, Granulocyte-monocyte colony-stimulating factor; GMPs, Granulocyte-monocyte progenitor cells; GPCR, $\mathrm{G}$ protein-coupled receptor; GTP, Guanosine triphosphate; HIF, Hypoxia-inducible factor; HL-60, Human leukemia-60 cell line; iC3b, inactivated C3b; ICAM-1, Intercellular adhesion molecule 1 ; IFN- $\beta$, Interferon $\beta$; IL, Interleukin; IgG, Immunoglobulin G; iPSC, Induced pluripotent stem cell; KLF4, Kruppel-like factor 4; LDN, Low-density neutrophil; LOX-1, Lectin-type oxidized LDL receptor 1; LPS, Lipopolysaccharide; LTB4, Leukotriene B4; Mac-1, Macrophage-1 antigen; MAPK, Mitogen-activated protein kinase; MBL, Mannose-binding lectin; MDSC, Myeloidderived suppressor cell; M-MDSC, Monocytic MDSC; MMP-9, Matrix metalloproteinase 9; MPO, Myeloperoxidase; MSU, Monosodium urate; NADPH, Nicotinamide adenine dinucleotide phosphate (reduced form); NDN, Normal-density neutrophil; NE, Neutrophil elastase; NET, Neutrophil extracellular trap; NF- $\mathrm{B}$, Nuclear factor kappa-light-chain enhancer of activated B cells; NOX2, NADPH oxidase 2; OCT4, Octamer-binding transcription factor 4; OLFM4, Olfactomedin 4; PAD4, protein arginase deiminase 4; PAF, Platelet-activating factor; PAK, p21activated kinase; PBMC, Peripheral blood mononuclear cell; PBS, Phosphate-buffered saline; PI3K, Phosphoinositide 3 kinase; $\mathrm{PIP}_{3}$, Phosphatidylinositol(3,4,5)-phosphate; PKC, Protein kinase C; PLC, Phospholipase C; PMA, Phorbol 12myristate 13-acetate; PML, Promyelocytic leukemia; PMNMDSC, granulocytic MDSC; PSGL-1, P-selectin glycoprotein ligand 1; RA, Retinoic acid; Rac, Ras-related C3 botulinum toxin substrate; Rap1, Ras-related protein 1; RAR $\alpha$, Retinoic acid receptor A; Rho, Ras homolog; ROCK, Rho-associated coiled-coil-containing protein kinase; ROS, Reactive oxygen species; RPMI-1640, Roswell Park Memorial Institute 1640; RUNX1, Runt-related transcription factor; SCF, Stem cell factor; SLE, Systemic lupus erythematosus; SOX2, Sexdetermining region Y box-2; SPARC, Secreted protein acidic and rich in cysteine; TDM, Trehalose dimycolate; TGF- $\beta$, Transforming growth factor $\beta$; TNF- $\alpha$, Tumor necrosis factor $\alpha$; VE-cadherin, Vascular-endothelial cadherin; VEGF, Vascular-endothelial growth factor; VHL, Von HippelLindau tumor-suppressor protein.

\section{Author Contributions}

MB, MG and SS wrote and revised the manuscript. All authors made substantial contributions to conception and design, analysis and interpretation of available literature; 
took part in drafting the article or revising it critically; agreed to submit to the current journal; gave final approval of the version to be published; and agree to be accountable for all aspects of the work.

\section{Funding}

This work was supported by the Research Foundation Flanders (FWO-Vlaanderen) (G080818N and G0F719N) and by $\mathrm{C} 1$ funding of the KU Leuven (C16/17/010). Mieke Gouwy is a research expert funded by the Rega Foundation and Marfa Blanter obtained a PhD scholarship from the University of Leuven and the FWO-Vlaanderen.

\section{Disclosure}

The authors declare no competing interests in this work.

\section{References}

1. Coffelt SB, Wellenstein MD, de Visser KE. Neutrophils in cancer: neutral no more. Nat Rev Cancer. 2016;16(7):431-446. doi:10.1038/nrc.2016.52

2. Cowland JB, Borregaard N. Granulopoiesis and granules of human neutrophils. Immunol Rev. 2016;273(1):11-28. doi:10.1111/imr.12440

3. Faurschou M, Borregaard N. Neutrophil granules and secretory vesicles in inflammation. Microbes Infect. 2003;5(14):1317-1327. doi:10.1016/j.micinf.2003.09.008

4. Ley K, Hoffman HM, Kubes P, et al. Neutrophils: new insights and open questions. Sci Immunol. 2018;3(30):eaat4579. doi:10.1126/sciimmunol.aat4579

5. Manz MG, Boettcher S. Emergency granulopoiesis. Nat Rev Immunol. 2014;14(5):302-314. doi:10.1038/nri3660

6. Pillay J, Kamp VM, van Hoffen E, et al. A subset of neutrophils in human systemic inflammation inhibits T cell responses through Mac-1. J Clin Invest. 2012;122(1):327-336. doi:10.1172/ JCI57990

7. Elghetany MT. Surface antigen changes during normal neutrophilic development: a critical review. Blood Cells Mol Dis. 2002;28 (2):260-274. doi: $10.1006 / \mathrm{bcmd} .2002 .0513$

8. Martin C, Burdon PC, Bridger G, Gutierrez-Ramos JC, Williams TJ, Rankin SM. Chemokines acting via CXCR2 and CXCR4 control the release of neutrophils from the bone marrow and their return following senescence. Immunity. 2003;19 (4):583-593. doi:10.1016/S1074-7613(03)00263-2

9. Ella K, Csépányi-Kömi R, Káldi K. Circadian regulation of human peripheral neutrophils. Brain Behav Immun. 2016;57:209-221. doi:10.1016/j.bbi.2016.04.016

10. Nourshargh S, Renshaw SA, Imhof BA. Reverse migration of neutrophils: where, when, how, and why? Trends Immunol. 2016;37(5):273-286. doi:10.1016/j.it.2016.03.006

11. Leliefeld PHC, Pillay J, Vrisekoop N, et al. Differential antibacterial control by neutrophil subsets. Blood Adv. 2018;2 (11):1344-1355. doi:10.1182/bloodadvances.2017015578

12. Uhl B, Vadlau Y, Zuchtriegel G, et al. Aged neutrophils contribute to the first line of defense in the acute inflammatory response. Blood. 2016;128(19):2327-2337. doi:10.1182/blood-2016-05-718999

13. Marini O, Costa S, Bevilacqua D, et al. Mature CD10 + and immature CD10 - neutrophils present in G-CSF-treated donors display opposite effects on $\mathrm{T}$ cells. Blood. 2017;129 (10):1343-1356. doi:10.1182/blood-2016-04-713206
14. Hassani M, Hellebrekers $\mathrm{P}$, Chen $\mathrm{N}$, et al. On the origin of low-density neutrophils. J Leukoc Biol. 2020;107(5):809-818. doi:10.1002/JLB.5HR0120-459R

15. Tay SH, Celhar T, Fairhurst AM. Low-density neutrophils in systemic lupus erythematosus. Arthritis Rheumatol. 2020;72 (10):1587-1595. doi:10.1002/art.41395

16. O'Neil LJ, Kaplan MJ. Neutrophils in rheumatoid arthritis: breaking immune tolerance and fueling disease. Trends Mol Med. 2019;25(3):215-227. doi:10.1016/j.molmed.2018.12.008

17. Silvestre-Roig C, Fridlender ZG, Glogauer M, Scapini P. Neutrophil diversity in health and disease. Trends Immunol. 2019;40(7):565-583. doi:10.1016/j.it.2019.04.012

18. Masucci MT, Minopoli M, Carriero MV. Tumor associated neutrophils. Their role in tumorigenesis, metastasis, prognosis and therapy. Front Oncol. 2019;9:1146. doi:10.3389/fonc.2019.01146

19. De Cicco P, Ercolano G, Ianaro A. The new era of cancer immunotherapy: targeting myeloid-derived suppressor cells to overcome immune evasion. Front Immunol. 2020;11:1680.

20. Giese MA, Hind LE, Huttenlocher A. Neutrophil plasticity in the tumor microenvironment. Blood. 2019;133(20):2159-2167. doi:10.1182/blood-2018-11-844548

21. Talmadge JE. Pathways mediating the expansion and immunosuppressive activity of myeloid-derived suppressor cells and their relevance to cancer therapy. Clin Cancer Res. 2007;13 (18):5243-5248. doi:10.1158/1078-0432.CCR-07-0182

22. Condamine T, Dominguez GA, Youn JI, et al. Lectin-type oxidized LDL receptor-1 distinguishes population of human polymorphonuclear myeloid-derived suppressor cells in cancer patients. Sci Immunol. 2016;1(2):aaf8943. doi:10.1126/sciimmunol.aaf8943

23. Sangaletti S, Talarico G, Chiodoni $C$, et al. SPARC is a new myeloid-derived suppressor cell marker licensing suppressive activities. Front Immunol. 2019;10:1369. doi:10.3389/fimmu.2019.01369

24. Magcwebeba T, Dorhoi A, Du Plessis N. The emerging role of myeloid-derived suppressor cells in tuberculosis. Front Immunol. 2019;10:917. doi:10.3389/fimmu.2019.00917

25. O'Connor MA, Rastad JL, Green WR. The role of myeloid-derived suppressor cells in viral infection. Viral Immunol. 2017;30(2):82-97. doi:10.1089/vim.2016.0125

26. Boros P, Ochando J, Zeher M. Myeloid derived suppressor cells and autoimmunity. Hum Immunol. 2016;77(8):631-636. doi:10.1016/j.humimm.2016.05.024

27. Cockx M, Gouwy M, Van Damme J, Struyf S. Chemoattractants and cytokines in primary ciliary dyskinesia and cystic fibrosis: key players in chronic respiratory diseases. Cell Mol Immunol. 2018;15(4):312-323. doi:10.1038/cmi.2017.118

28. De Bondt M, Hellings N, Opdenakker G, Struyf S. Neutrophils: underestimated players in the pathogenesis of Multiple Sclerosis (MS). Int J Mol Sci. 2020;21(12):4558. doi:10.3390/ijms21124558

29. Rapoport BL, Steel HC, Theron AJ, Smit T, Anderson R. Role of the neutrophil in the pathogenesis of advanced cancer and impaired responsiveness to therapy. Molecules. 2020;25(7):1618. doi:10.3390/molecules 25071618

30. Summers C, Rankin SM, Condliffe AM, Singh N, Peters AM, Chilvers ER. Neutrophil kinetics in health and disease. Trends Immunol. 2010;31(8):318-324. doi:10.1016/j.it.2010.05.006

31. Scheel-Toellner D, Wang K, Craddock R, et al. Reactive oxygen species limit neutrophil life span by activating death receptor signaling. Blood. 2004;104(8):2557-2564. doi:10.1182/blood2004-01-0191

32. Birnie GD. The HL60 cell line: a model system for studying human myeloid cell differentiation. $B r J$ Cancer Suppl. 1988;9:41-45.

33. Newburger PE, Chovaniec ME, Greenberger JS, Cohen HJ. Functional changes in human leukemic cell line HL-60. A model for myeloid differentiation. J Cell Biol. 1979;82 (2):315-322. doi: $10.1083 / \mathrm{jcb} .82 .2 .315$ 
34. Fu S, Fu Y, Chen F, Hu Y, Quan B, Zhang J. Overexpression of MYCT1 inhibits proliferation and induces apoptosis in human acute myeloid leukemia HL-60 and KG-1a cells. Front Pharmacol. 2018;9:1045. doi:10.3389/fphar.2018.01045

35. Narimani M, Sharifi M, Jalili A. Knockout of BIRC5 gene by CRISPR/Cas9 induces apoptosis and inhibits cell proliferation in leukemic cell lines, HL60 and KG1. Blood Lymphat Cancer. 2019;9:53-61. doi:10.2147/BLCTT.S230383

36. Bao S, He D, Zeng J, Zhang Y, Chen S. Effect of miRNA-19a antisense oligonucleotide and Ara-C on the proliferation and apoptosis of HL60 cells. Ann Transl Med. 2019;7(12):260. doi:10.21037/atm.2019.05.32

37. Song G, Shi L, Guo Y, et al. A novel PAD4/SOX4/PU.1 signaling pathway is involved in the committed differentiation of acute promyelocytic leukemia cells into granulocytic cells. Oncotarget. 2016;7(3):3144-3157. doi:10.18632/oncotarget.6551

38. Millius A, Weiner OD. Manipulation of neutrophil-like HL-60 cells for the study of directed cell migration. Methods Mol Biol. 2010;591:147-158.

39. Breitman TR, Selonick SE, Collins SJ. Induction of differentiation of the human promyelocytic leukemia cell line (HL-60) by retinoic acid. Proc Natl Acad Sci U S A. 1980;77(5):2936-2940. doi:10.1073/pnas.77.5.2936

40. Tarella C, Ferrero D, Gallo E, Pagliardi GL, Ruscetti FW. Induction of differentiation of HL-60 cells by dimethyl sulfoxide: evidence for a stochastic model not linked to the cell division cycle. Cancer Res. 1982;42(2):445-449.

41. Graziano RF, Ball ED, Fanger MW. The expression and modulation of human myeloid-specific antigens during differentiation of the HL-60 cell line. Blood. 1983;61(6):1215-1221. doi:10.1182/ blood.V61.6.1215.1215

42. Lotem J, Sachs L. Potential pre-screening for therapeutic agents that induce differentiation in human myeloid leukemia cells. Int J Cancer. 1980;25(5):561-564. doi:10.1002/ijc.2910250503

43. Chaplinski TJ, Niedel JE. Cyclic nucleotide-induced maturation of human promyelocytic leukemia cells. J Clin Invest. 1982;70 (5):953-964. doi:10.1172/JCI110707

44. Mangasarian K, Mellon WS. 1,25-Dihydroxyvitamin D-3 destabilizes c-myc mRNA in HL-60 leukemic cells. Biochim Biophys Acta. 1993;1172(1-2):55-63. doi:10.1016/0167-4781(93)90269-J

45. Collins SJ. The HL-60 promyelocytic leukemia cell line: proliferation, differentiation, and cellular oncogene expression. Blood. 1987;70(5):1233-1244. doi:10.1182/blood.V70.5.1233.1233

46. Robson S, Pelengaris S, Khan M. c-Myc and downstream targets in the pathogenesis and treatment of cancer. Recent Pat Anticancer Drug Discov. 2006;1(3):305-326. doi:10.2174/ 157489206778776934

47. Antoun GR, Re GG, Terry NH, Zipf TF. Molecular genetic evidence for a differentiation-proliferation coupling during DMSO-induced myeloid maturation of HL-60 cells: role of the transcription elongation block in the c-myc gene. Leuk Res. 1991;15(11):1029-1036. doi:10.1016/0145-2126(91)90108-6

48. Von Hoff DD, Forseth B, Clare CN, Hansen KL, VanDevanter D. Double minutes arise from circular extrachromosomal DNA intermediates which integrate into chromosomal sites in human HL-60 leukemia cells. $J$ Clin Invest. 1990;85(6):1887-1895. doi:10.1172/JCI114650

49. Shimizu N, Nakamura $H$, Kadota $T$, et al. Loss of amplified c-myc genes in the spontaneously differentiated HL-60 cells. Cancer Res. 1994;54(13):3561-3567.

50. Wickstrom EL, Bacon TA, Gonzalez A, Freeman DL, Lyman GH, Wickstrom E. Human promyelocytic leukemia HL-60 cell proliferation and c-myc protein expression are inhibited by an antisense pentadecadeoxynucleotide targeted against c-myc mRNA. Proc Natl Acad Sci U S A. 1988;85(4):1028-1032. doi:10.1073/ pnas.85.4.1028
51. Kimura S, Maekawa T, Hirakawa K, Murakami A, Abe T. Alterations of c-myc expression by antisense oligodeoxynucleotides enhance the induction of apoptosis in HL-60 cells. Cancer Res. 1995;55(6):1379-1384.

52. Martino OD, Welch JS. Retinoic acid receptors in acute myeloid leukemia therapy. Cancers (Basel). 2019;11(12):1915. doi:10.3390/cancers11121915

53. Grace CS, Mikkola HKA, Dou DR, Calvanese V, Ronn RE, Purton LE. Protagonist or antagonist? The complex roles of retinoids in the regulation of hematopoietic stem cells and their specification from pluripotent stem cells. Exp Hematol. 2018;65:1-16. doi:10.1016/j.exphem.2018.06.287

54. Hong HY, Varvayanis S, Yen A. Retinoic acid causes MEK-dependent RAF phosphorylation through RARalpha plus RXR activation in HL-60 cells. Differentiation. 2001;68 (1):55-66. doi:10.1046/j.1432-0436.2001.068001055.x

55. Bertagnolo V, Neri LM, Marchisio M, Mischiati C, Capitani S. Phosphoinositide 3-kinase activity is essential for all-transretinoic acid-induced granulocytic differentiation of HL-60 cells. Cancer Res. 1999;59(3):542-546.

56. Kambhampati S, Verma A, Li Y, Parmar S, Sassano A, Platanias LC. Signalling pathways activated by all-trans-retinoic acid in acute promyelocytic leukemia cells. Leuk Lymphoma. 2004;45(11):2175-2185. doi:10.1080/10428190410001722053

57. Bentley DL, Groudine M. A block to elongation is largely responsible for decreased transcription of c-myc in differentiated HL60 cells. Nature. 1986;321(6071):702-706. doi:10.1038/321702a0

58. Eick D. Elongation and maturation of c-myc RNA is inhibited by differentiation inducing agents in HL60 cells. Nucleic Acids Res. 1990;18(5):1199-1205. doi:10.1093/nar/18.5.1199

59. Eckhardt SG, Dai A, Davidson KK, Forseth BJ, Wahl GM, Von Hoff DD. Induction of differentiation in HL60 cells by the reduction of extrachromosomally amplified c-myc. Proc Natl Acad Sci U S A. 1994;91(14):6674-6678. doi:10.1073/pnas.91.14.6674

60. Kuliczkowski K, Darley RL, Jacobs A, Padua RA, Hoy TG. Upregulation of p21 RAS levels in HL-60 cells during differentiation induction with DMSO, all-trans-retinoic acid and TPA. Leuk Res. 1995;19(4):291-296. doi:10.1016/0145-2126(94)00161-3

61. Makowske M, Ballester R, Cayre Y, Rosen OM. Immunochemical evidence that three protein kinase $\mathrm{C}$ isozymes increase in abundance during HL-60 differentiation induced by dimethyl sulfoxide and retinoic acid. J Biol Chem. 1988;263 (7):3402-3410.

62. McEver RP. Selectins: initiators of leucocyte adhesion and signalling at the vascular wall. Cardiovasc Res. 2015;107(3):331-339. doi:10.1093/cvr/cvv154

63. Graham GJ, Handel TM, Proudfoot AEI. Leukocyte adhesion: reconceptualizing chemokine presentation by glycosaminoglycans. Trends Immunol. 2019;40(6):472-481. doi:10.1016/j.it.2019.03.009

64. Nourshargh S, Alon R. Leukocyte migration into inflamed tissues. Immunity. 2014;41(5):694-707. doi:10.1016/j.immuni.201 4.10.008

65. Metzemaekers M, Gouwy M, Proost P. Neutrophil chemoattractant receptors in health and disease: double-edged swords. Cell Mol Immunol. 2020;17(5):433-450.

66. Rot A, von Andrian UH. Chemokines in innate and adaptive host defense: basic chemokinese grammar for immune cells. Annu Rev Immunol. 2004;22:891-928. doi:10.1146/annurev.immunol.2 2.012703.104543

67. Gómez-Moutón C, Mañes S. Establishment and maintenance of cell polarity during leukocyte chemotaxis. Cell Adh Migr. 2007;1 (2):69-76. doi:10.4161/cam.1.2.4547

68. Lämmermann T, Germain RN. The multiple faces of leukocyte interstitial migration. Semin Immunopathol. 2014;36(2):227-251. doi:10.1007/s00281-014-0418-8 
69. Alon R, van Buul JD. Leukocyte breaching of endothelial barriers: the actin link. Trends Immunol. 2017;38(8):606-615. doi:10.1016/j.it.2017.05.002

70. Tardif M, Mery L, Brouchon L, Boulay F. Agonist-dependent phosphorylation of $\mathrm{N}$-formylpeptide and activation peptide from the fifth component of $\mathrm{C}$ (C5a) chemoattractant receptors in differentiated HL60 cells. $J$ Immunol. 1993;150(8 Pt 1):3534-3545.

71. Ye RD, Cavanagh SL, Quehenberger O, Prossnitz ER, Cochrane CG. Isolation of a cDNA that encodes a novel granulocyte N-formyl peptide receptor. Biochem Biophys Res Commun. 1992;184(2):582-589. doi:10.1016/0006-291X(92)90629-Y

72. Hu Y, Cheng N, Wu H, Kang S, Ye RD, Cai J. Design, synthesis and characterization of fMLF-mimicking Apeptides. Chembiochem. 2014;15(16):2420-2426. doi:10.1002/cbic.201402396

73. Masuda K, Kitakami JI, Kozasa T, Kodama T, Ihara S, Hamakubo T. Visualization of ligand-induced G. FASEB J. 2017;31(3):910-919. doi:10.1096/fj.201601102R

74. Burg M, Martin U, Bock D, et al. Differential regulation of the C3a and C5a receptors (CD88) by IFN-gamma and PMA in U937 cells and related myeloblastic cell lines. J Immunol. 1996;157 (12):5574-5581.

75. Klinker JF, Wenzel-Seifert K, Seifert R. G-protein-coupled receptors in HL-60 human leukemia cells. Gen Pharmacol. 1996;27 (1):33-54. doi:10.1016/0306-3623(95)00107-7

76. Kikuchi-Ueda $\mathrm{T}$, Tansho S, Ono $\mathrm{Y}$. Enhancement of interleukin-8-induced chemotactic response and reactive oxygen species production in HL-60 cells expressing CXCR1. J Infect Chemother. 2012;18(3):283-287. doi:10.1007/s10156-011-0321-3

77. Sai J, Walker G, Wikswo J, Richmond A. The IL sequence in the LLKIL motif in CXCR2 is required for full ligand-induced activation of Erk, Akt, and chemotaxis in HL60 cells. J Biol Chem. 2006;281(47):35931-35941. doi:10.1074/jbc.M605883200

78. Jacobs AA, Huber JL, Ward RA, Klein JB, McLeish KR. Chemoattractant receptor-specific differences in $\mathrm{G}$ protein activation rates regulate effector enzyme and functional responses. J Leukoc Biol. 1995;57(4):679-686. doi:10.1002/jlb.57.4.679

79. Erbeck K, Klein JB, McLeish KR. Differential uncoupling of chemoattractant receptors from $\mathrm{G}$ proteins in retinoic acid-differentiated HL-60 granulocytes. J Immunol. 1993;150 (5):1913-1921.

80. Fontana JA, Wright DG, Schiffman E, Corcoran BA, Deisseroth AB. Development of chemotactic responsiveness in myeloid precursor cells: studies with a human leukemia cell line. Proc Natl Acad Sci U S A. 1980;77(6):3664-3668. doi:10.1073/ pnas.77.6.3664

81. Chaplinski TJ, Sloan GJ, Niedel JE. Granulocyte functions during maturation of human promyelocytic leukemia cells. Leuk Res. 1985;9(7):897-903. doi:10.1016/0145-2126(85)90311-X

82. Sjögren F, Stendahl O, Ljunghusen O. The influence of retinoic acid and retinoic acid derivatives on beta2 integrins and L-selectin expression in HL-60 cells in vitro. Inflammation. 2000;24(1):21-32. doi:10.1023/A:1006983824890

83. Gee DJ, Wright LK, Zimmermann J, Cole K, Soule K, Ubowski M. Dimethylsulfoxide exposure modulates HL-60 cell rolling interactions. Biosci Rep. 2012;32(4):375-382. doi:10.1042/BSR20110109

84. Nordenfelt P, Bauer S, Lönnbro P, Tapper H. Phagocytosis of Streptococcus pyogenes by all-trans retinoic acid-differentiated HL-60 cells: roles of azurophilic granules and NADPH oxidase. PLoS One. 2009;4(10):e7363. doi:10.1371/journal.pone.0007363

85. Bellón T, López-Rodríguez C, Rubio MA, Jochems G, Bernabeu C, Corbi AL. Regulated expression of p150,95 (CD11c/CD18; alpha X/beta 2) and VLA-4 (CD49d/CD29; alpha 4/beta 1) integrins during myeloid cell differentiation. Eur J Immunol. 1994;24(1):41-47. doi:10.1002/eji.1830240107
86. Sham RL, Phatak PD, Belanger KA, Packman CH. Functional properties of HL60 cells matured with all-trans-retinoic acid and DMSO: differences in response to interleukin-8 and fMLP. Leuk Res. 1995;19(1):1-6. doi:10.1016/0145-2126(94)00063-G

87. Matzner Y, Gavison R, Rachmilewitz EA, Fibach E. Expression of granulocytic functions by leukemic promyelocytic HL-60 cells: differential induction by dimethylsulfoxide and retinoic acid. Cell Differ. 1987;21(4):261-269. doi:10.1016/0045-6039(87)90481-7

88. Carrigan SO, Pink DB, Stadnyk AW. Neutrophil transepithelial migration in response to the chemoattractant AMLP but not C5a is phospholipase D-dependent and related to the use of CD11b/CD18. J Leukoc Biol. 2007;82(6):1575-1584. doi:10.1189/jlb.0806528

89. Hauert AB, Martinelli S, Marone C, Niggli V. Differentiated HL-60 cells are a valid model system for the analysis of human neutrophil migration and chemotaxis. Int J Biochem Cell Biol. 2002;34(7):838-854. doi:10.1016/S1357-2725(02)00010-9

90. Rao KM, Currie MS, Cohen HJ, Weinberg JB. Chemotactic peptide receptor-cytoskeletal interactions and functional correlations in differentiated HL-60 cells and human polymorphonuclear leukocytes. J Cell Physiol. 1989;141(1):119-125. doi:10.1002/ jcp. 1041410118

91. Meyer WH, Howard TH. Changes in actin content during induced myeloid maturation of human promyelocytes. Blood. 1983;62 (2):308-314. doi:10.1182/blood.V62.2.308.308

92. Prossnitz ER, Quehenberger O, Cochrane CG, Ye RD. Signal transducing properties of the $\mathrm{N}$-formyl peptide receptor expressed in undifferentiated HL60 cells. $J$ Immunol. 1993;151 (10):5704-5715.

93. Stadtmann A, Zarbock A. CXCR2: from bench to bedside. Front Immunol. 2012;3:263. doi:10.3389/fimmu.2012.00263

94. Garner RM, Skariah G, Hadjitheodorou A, et al. Neutrophil-like HL-60 cells expressing only GFP-tagged $\beta$-actin exhibit nearly normal motility. Cytoskeleton (Hoboken). 2020;77(5-6):181-196. doi:10.1002/cm.21603

95. Uribe-Querol E, Rosales C. Phagocytosis: our current understanding of a universal biological process. Front Immunol. 2020;11:1066. doi:10.3389/fimmu.2020.01066

96. Wang Y, Jönsson F. Expression, role, and regulation of neutrophil Fc $\gamma$ receptors. Front Immunol. 2019;10:1958. doi:10.3389/ fimmu.2019.01958

97. Dunkelberger JR, Song WC. Complement and its role in innate and adaptive immune responses. Cell Res. 2010;20(1):34-50. doi:10.1038/cr.2009.139

98. Yin C, Heit B. Armed for destruction: formation, function and trafficking of neutrophil granules. Cell Tissue Res. 2018;371 (3):455-471. doi:10.1007/s00441-017-2731-8

99. Nordenfelt P, Tapper H. Phagosome dynamics during phagocytosis by neutrophils. $J$ Leukoc Biol. 2011;90(2):271-284. doi:10.1189/jlb.0810457

100. Miralda I, Uriarte SM, McLeish KR. Multiple phenotypic changes define neutrophil priming. Front Cell Infect Microbiol. 2017;7:217. doi:10.3389/fcimb.2017.00217

101. Nepomuceno RR, Tenner AJ. C1qRP, the $\mathrm{C} 1 \mathrm{q}$ receptor that enhances phagocytosis, is detected specifically in human cells of myeloid lineage, endothelial cells, and platelets. J Immunol. 1998;160(4):1929-1935.

102. Eggleton P, Ghebrehiwet B, Coburn JP, Sastry KN, Zaner KS, Tauber AI. Characterization of the human neutrophil $\mathrm{Clq}$ receptor and functional effects of free ligand on activated neutrophils. Blood. 1994;84(5):1640-1649. doi:10.1182/blood.V84.5.1640.1640

103. Kim JH, Lee S, Choe SY. Characterization of the human CR1 gene promoter. Biochem Mol Biol Int. 1999;47(4):655-663. doi:10.1080/15216549900201713

104. Yanagida M, Nakayama H, Yoshizaki F, et al. Proteomic analysis of plasma membrane lipid rafts of HL-60 cells. Proteomics. 2007;7(14):2398-2409. doi:10.1002/pmic.200700056 
105. Funkhouser TA, Vik DP. Complement receptor type 1 gene regulation: retinoic acid and cytosine arabinoside increase CR1 expression. Scand J Immunol. 1999;49(1):21-28. doi:10.1046/ j.1365-3083.1999.00455.x

106. Hickstein DD, Back AL, Collins SJ. Regulation of expression of the CD11b and CD18 subunits of the neutrophil adherence receptor during human myeloid differentiation. J Biol Chem. 1989;264 (36):21812-21817.

107. Shen L, Graziano RF, Fanger MW. The functional properties of Fc gamma RI, II and III on myeloid cells: a comparative study of killing of erythrocytes and tumor cells mediated through the different Fc receptors. Mol Immunol. 1989;26(10):959-969. doi:10.1016/0161-5890(89)90114-4

108. Erbe DV, Collins JE, Shen L, Graziano RF, Fanger MW. The effect of cytokines on the expression and function of Fc receptors for IgG on human myeloid cells. Mol Immunol. 1990;27 (1):57-67. doi:10.1016/0161-5890(90)90060-D

109. Kim KH, Seoh JY, Cho SJ. Phenotypic and functional analysis of HL-60 cells used in opsonophagocytic-killing assay for Streptococcus pneumoniae. J Korean Med Sci. 2015;30 (2):145-150. doi:10.3346/jkms.2015.30.2.145

110. Wightman J, Roberson MS, Lamkin TJ, Varvayanis S, Yen A. Retinoic acid-induced growth arrest and differentiation: retinoic acid up-regulates CD32 (Fc gammaRII) expression, the ectopic expression of which retards the cell cycle. Mol Cancer Ther. 2002;1(7):493-506.

111. Chen ML, Wu S, Tsai TC, Wang LK, Tsai FM. Regulation of neutrophil phagocytosis of Escherichia coli by antipsychotic drugs. Int Immunopharmacol. 2014;23(2):550-557. doi:10.1016/ j.intimp.2014.09.030

112. Roberts PJ, Ford JM. A new combined assay of phagocytosis and intracellular killing of Escherichia coli by polymorphonuclear leukocytes. J Immunol Methods. 1982;49(2):193-207. doi:10.1016/0022-1759(82)90277-0

113. Stendahl O, Dahlgren C, Hed J. Physicochemical and functional changes in human leukemic cell line HL-60. J Cell Physiol. 1982;112(2):217-221. doi:10.1002/jcp.1041120209

114. McGregor R, Jones S, Jeremy RM, Goldblatt D, Moreland NJ. An opsonophagocytic killing assay for the evaluation of group A streptococcus vaccine antisera. Methods Mol Biol. 2020;2136:323-335.

115. Salehi S, Hohn CM, Penfound TA, Dale JB. Development of an opsonophagocytic killing assay using HL-60 cells for detection of functional antibodies against Streptococcus pyogenes. mSphere. 2018;3(6):e00617-e00618. doi:10.1128/ mSphere.00617-18

116. Fleck RA, Romero-Steiner S, Nahm MH. Use of HL-60 cell line to measure opsonic capacity of pneumococcal antibodies. Clin Diagn Lab Immunol. 2005;12(1):19-27. doi:10.1128/ CDLI.12.1.19-27.2005

117. Lerm M, Brodin VP, Ruishalme I, Stendahl O, Särndahl E. Inactivation of $\mathrm{Cdc} 42$ is necessary for depolymerization of phagosomal F-actin and subsequent phagosomal maturation. J Immunol. 2007;178 (11):7357-7365. doi:10.4049/jimmunol.178.11.7357

118. Pullen GR, Hosking CS. Differentiated HL60 promyelocytic leukaemia cells have a deficient myeloperoxidase/halide killing system. Clin Exp Immunol. 1985;62(2):304-309.

119. Yaseen R, Blodkamp S, Lüthje P, et al. Antimicrobial activity of HL-60 cells compared to primary blood-derived neutrophils against Staphylococcus aureus. J Negat Results Biomed. 2017;16(1):2. doi:10.1186/s12952-017-0067-2

120. Panday A, Sahoo MK, Osorio D, Batra S. NADPH oxidases: an overview from structure to innate immunity-associated pathologies. Cell Mol Immunol. 2015;12(1):5-23.
121. El-Benna J, Dang PM, Gougerot-Pocidalo MA. Priming of the neutrophil NADPH oxidase activation: role of $\mathrm{p} 47$ phox phosphorylation and NOX2 mobilization to the plasma membrane. Semin Immunopathol. 2008;30(3):279-289. doi:10.1007/s00281-0080118-3

122. Winterbourn CC, Kettle AJ, Hampton MB. Reactive oxygen species and neutrophil function. Annu Rev Biochem. 2016;85:765-792. doi:10.1146/annurev-biochem-060815-014442

123. Nauseef WM, Olsson I, Arnljots K. Biosynthesis and processing of myeloperoxidase - a marker for myeloid cell differentiation. Eur J Haematol. 1988;40(2):97-110. doi:10.1111/j.16000609.1988.tb00805.x

124. Teufelhofer O, Weiss RM, Parzefall W, et al. Promyelocytic HL60 cells express NADPH oxidase and are excellent targets in a rapid spectrophotometric microplate assay for extracellular superoxide. Toxicol Sci. 2003;76(2):376-383. doi:10.1093/ toxsci/kfg234

125. Dong JM, Zhao SG, Huang GY, Liu Q. NADPH oxidase-mediated generation of reactive oxygen species is critically required for survival of undifferentiated human promyelocytic leukemia cell line HL-60. Free Radic Res. 2004;38 (6):629-637. doi:10.1080/10715760410001694053

126. Kitagawa S, Ohta M, Nojiri H, et al. Functional maturation of membrane potential changes and superoxide-producing capacity during differentiation of human granulocytes. J Clin Invest. 1984;73(4):1062-1071. doi:10.1172/JCI111291

127. Thompson BY, Sivam G, Britigan BE, Rosen GM, Cohen MS. Oxygen metabolism of the HL-60 cell line: comparison of the effects of monocytoid and neutrophilic differentiation. J Leukoc Biol. 1988;43(2):140-147. doi:10.1002/jlb.43.2.140

128. Korchak HM, Rossi MW, Kilpatrick LE. Selective role for beta-protein kinase $\mathrm{C}$ in signaling for $\mathrm{O}-2$ generation but not degranulation or adherence in differentiated HL60 cells. $J$ Biol Chem. 1998;273(42):27292-27299. doi:10.1074/ jbc.273.42.27292

129. Waki K, Inanami O, Yamamori $T$, Nagahata H, Kuwabara M. Involvement of protein kinase Cdelta in the activation of NADPH oxidase and the phagocytosis of neutrophils. Free Radic Res. 2006;40(4):359-367. doi:10.1080/10715760500539121

130. Kikuchi-Ueda T, Ubagai T, Ono Y. Priming effects of tumor necrosis factor- $\alpha$ on production of reactive oxygen species during Toxoplasma gondii stimulation and receptor gene expression in differentiated HL-60 cells. J Infect Chemother. 2013;19 (6):1053-1064. doi:10.1007/s10156-013-0619-4

131. Seitz PM, Cooper R, Gatto GJ, et al. Development of a high-throughput cell-based assay for superoxide production in HL-60 cells. J Biomol Screen. 2010;15(4):388-397. doi:10.1177/ 1087057109359687

132. Van Avondt K, Hartl D. Mechanisms and disease relevance of neutrophil extracellular trap formation. Eur J Clin Invest. 2018;48 (Suppl 2):e12919. doi:10.1111/eci.12919

133. Yang H, Biermann MH, Brauner JM, Liu Y, Zhao Y, Herrmann M. New insights into neutrophil extracellular traps: mechanisms of formation and role in inflammation. Front Immunol. 2016;7:302. doi:10.3389/fimmu.2016.00302

134. Thiam HR, Wong SL, Qiu R, et al. NETosis proceeds by cytoskeleton and endomembrane disassembly and PAD4-mediated chromatin decondensation and nuclear envelope rupture. Proc Natl Acad Sci U S A. 2020;117(13):7326-7337. doi:10.1073/ pnas. 1909546117

135. Brinkmann V, Reichard U, Goosmann C, et al. Neutrophil extracellular traps kill bacteria. Science. 2004;303(5663):1532-1535. doi:10.1126/science. 1092385 
136. Rada B. Neutrophil extracellular traps and microcrystals J Immunol Res. 2017;2017:2896380. doi:10.1155/2017/2896380

137. Neubert E, Meyer D, Kruss S, Erpenbeck L. The power from within - understanding the driving forces of neutrophil extracellular trap formation. $J$ Cell Sci. 2020;133(5):jcs241075. doi: $10.1242 /$ jcs. 241075

138. Wolfson M, McPhail LC, Nasrallah VN, Snyderman R. Phorbol myristate acetate mediates redistribution of protein kinase $\mathrm{C}$ in human neutrophils: potential role in the activation of the respiratory burst enzyme. J Immunol. 1985;135(3):2057-2062.

139. Mahomed AG, Anderson R. Activation of human neutrophils with chemotactic peptide, opsonized zymosan and the calcium ionophore A23187, but not with a phorbol ester, is accompanied by efflux and store-operated influx of calcium. Inflammation. 2000;24(6):559-569. doi:10.1023/A:1007029524141

140. Neeli I, Khan SN, Radic M. Histone deimination as a response to inflammatory stimuli in neutrophils. $J$ Immunol. 2008;180 (3):1895-1902. doi:10.4049/jimmunol.180.3.1895

141. Wang Y, Li M, Stadler S, et al. Histone hypercitrullination mediates chromatin decondensation and neutrophil extracellular trap formation. J Cell Biol. 2009;184(2):205-213. doi:10.1083/jcb.200806072

142. Manda-Handzlik A, Bystrzycka W, Wachowska M, et al. The influence of agents differentiating HL-60 cells toward granulocyte-like cells on their ability to release neutrophil extracellular traps. Immunol Cell Biol. 2018;96(4):413-425. doi:10.1111/imcb.12015

143. Takishita Y, Yasuda H, Shimizu M, et al. Formation of neutrophil extracellular traps in mitochondrial DNA-deficient cells. J Clin Biochem Nutr. 2020;66(1):15-23. doi:10.3164/jcbn.19-77

144. $\mathrm{Xu} \mathrm{Z,} \mathrm{Ni} \mathrm{B,} \mathrm{Cao} \mathrm{Z,} \mathrm{et} \mathrm{al.} \mathrm{Kindlin-3} \mathrm{negatively} \mathrm{regulates} \mathrm{the}$ release of neutrophil extracellular traps. $J$ Leukoc Biol. 2018;104(3):597-602. doi:10.1002/JLB.3AB0118-005R

145. Zhang Y, Wilt E, Lu X. Human isogenic cell line models for neutrophils and myeloid-derived suppressor cells. Int $J \mathrm{Mol} \mathrm{Sci}$. 2020;21(20):7709. doi:10.3390/ijms21207709

146. Marques-Silva VM, De Souza MH, Teixeira MC, Arcuri RA, Rumjanek VM. Myeloid leukemia differentiation by phorbol ester and retinoic acid: a practical approach. J Clin Lab Anal. 1990;4(5):342-349. doi:10.1002/jcla.1860040506

147. Romero-Steiner S, Libutti D, Pais LB, et al. Standardization of an opsonophagocytic assay for the measurement of functional antibody activity against Streptococcus pneumoniae using differentiated HL-60 cells. Clin Diagn Lab Immunol. 1997;4(4):415-422. doi:10.1128/CDLI.4.4.415-422.1997

148. Paschall AV, Middleton DR, Avci FY. Opsonophagocytic killing assay to assess immunological responses against bacterial pathogens. J Vis Exp. 2019;(146). doi:10.3791/59400

149. Tucker KA, Lilly MB, Heck L, Rado TA. Characterization of a new human diploid myeloid leukemia cell line (PLB-985) with granulocytic and monocytic differentiating capacity. Blood. 1987;70(2):372-378. doi:10.1182/blood.V70.2.372.372

150. Rincón E, Rocha-Gregg BL, Collins SR. A map of gene expression in neutrophil-like cell lines. BMC Genom. 2018;19(1):573. doi:10.1186/s12864-018-4957-6

151. Drexler HG, Dirks WG, Matsuo Y, MacLeod RA. False leukemia-lymphoma cell lines: an update on over 500 cell lines. Leukemia. 2003;17(2):416-426. doi:10.1038/sj.leu.2402799

152. Lanotte M, Martin-Thouvenin V, Najman S, Balerini P, Valensi F, Berger R. NB4, a maturation inducible cell line with $t(15 ; 17)$ marker isolated from a human acute promyelocytic leukemia (M3). Blood. 1991;77(5):1080-1086. doi:10.1182/blood. V77.5.1080.1080
153. N'Diaye EN, Vaissiere C, Gonzalez-Christen J, Grégoire C, Le Cabec V, Maridonneau-Parini I. Expression of NADPH oxidase is induced by all-trans retinoic acid but not by phorbol myristate acetate and 1,25 dihydroxyvitamin D3 in the human promyelocytic cell line NB4. Leukemia. 1997;11(12):2131-2136. doi:10.1038/sj.leu.2400855

154. Khanna-Gupta A, Kolibaba K, Zibello TA, Berliner N. NB4 cells show bilineage potential and an aberrant pattern of neutrophil secondary granule protein gene expression. Blood. 1994;84 (1):294-302. doi:10.1182/blood.V84.1.294.294

155. Mozziconacci MJ, Rosenauer A, Restouin A, et al. Molecular cytogenetics of the acute promyelocytic leukemia-derived cell line NB4 and of four all-trans retinoic acid-resistant subclones. Genes Chromosomes Cancer. 2002;35(3):261-270. doi:10.1002/ gcc. 10117

156. Grégoire C, Welch H, Astarie-Dequeker C, Maridonneau-Parini I. Expression of azurophil and specific granule proteins during differentiation of NB4 cells in neutrophils. $J$ Cell Physiol. 1998;175(2):203-210. doi:10.1002/(SICI)1097-4652(199805) 175:2<203::AID-JCP10>3.0.CO;2-9

157. Pass MB, Borregaard N, Cowland JB. Derangement of transcription factor profiles during in vitro differentiation of HL60 and NB4 cells. Leuk Res. 2007;31(6):827-837. doi:10.1016/j. leukres.2006.07.019

158. Shibakura M, Niiya K, Kiguchi T, et al. Simultaneous induction of matrix metalloproteinase- 9 and interleukin 8 by all-trans retinoic acid in human PL-21 and NB4 myeloid leukaemia cells. $B r$ $J \quad$ Haematol. 2002;118(2):419-425. doi:10.1046/j.13652141.2002.03723.x

159. Barber N, Belov L, Christopherson RI. All-trans retinoic acid induces different immunophenotypic changes on human HL60 and NB4 myeloid leukaemias. Leuk Res. 2008;32(2):315-322. doi:10.1016/j.leukres.2007.04.013

160. Asou H, Tashiro S, Hamamoto K, Otsuji A, Kita K, Kamada N. Establishment of a human acute myeloid leukemia cell line (Kasumi-1) with 8;21 chromosome translocation. Blood. 1991;77(9):2031-2036. doi:10.1182/blood.V77.9.2031.2031

161. Schoenherr C, Wohlan K, Dallmann I, et al. Stable depletion of RUNX1-ETO in Kasumi-1 cells induces expression and enhanced proteolytic activity of Cathepsin G and neutrophil elastase. PLoS One. 2019;14(12):e0225977. doi:10.1371/journal.pone.0225977

162. Karagiannis $\mathrm{P}$, Takahashi K, Saito M, et al. Induced pluripotent stem cells and their use in human models of disease and development. Physiol Rev. 2019;99(1):79-114. doi:10.1152/ physrev.00039.2017

163. Xiao X, Li N, Zhang D, Yang B, Guo H, Li Y. Generation of induced pluripotent stem cells with substitutes for yamanaka's four transcription factors. Cell Reprogram. 2016;18(5):281-297. doi:10.1089/cell.2016.0020

164. Fernandes S, Khan N, Kale V, Limaye L. Catalase incorporation in freezing mixture leads to improved recovery of cryopreserved iPSC lines. Cryobiology. 2019;90:21-29. doi:10.1016/j. cryobiol.2019.09.003

165. Hwang Y, Broxmeyer HE, Lee MR. Generating autologous hematopoietic cells from human-induced pluripotent stem cells through ectopic expression of transcription factors. Curr Opin Hematol. 2017;24(4):283-288. doi:10.1097/MOH.0000000000000343

166. Morishima T, Watanabe K, Niwa A, et al. Neutrophil differentiation from human-induced pluripotent stem cells. $J$ Cell Physiol. 2011;226(5):1283-1291. doi:10.1002/jcp.22456

167. Sweeney CL, Merling RK, Choi U, et al. Generation of functionally mature neutrophils from induced pluripotent stem cells. Methods Mol Biol. 2014;1124:189-206. 
168. Lachmann N, Ackermann M, Frenzel E, et al. Large-scale hematopoietic differentiation of human induced pluripotent stem cells provides granulocytes or macrophages for cell replacement therapies. Stem Cell Rep. 2015;4(2):282-296. doi:10.1016/j. stemcr.2015.01.005

169. Trump LR, Nayak RC, Singh AK, et al. Neutrophils derived from genetically modified human induced pluripotent stem cells circulate and phagocytose bacteria in vivo. Stem Cells Transl Med. 2019;8(6):557-567. doi:10.1002/sctm.18-0255

170. Brault J, Goutagny E, Telugu N, et al. Optimized generation of functional neutrophils and macrophages from patient-specific induced pluripotent stem cells: ex vivo models of $\mathrm{X}(0)$-linked, AR22(0)- and AR47(0)- chronic granulomatous diseases. Biores Open Access. 2014;3(6):311-326. doi:10.1089/biores.2014.0045

171. Wu X, Lin M, Li Y, Zhao X, Yan F. Effects of DMEM and RPMI 1640 on the biological behavior of dog periosteum-derived cells. Cytotechnology. 2009;59(2):103-111. doi:10.1007/s10616-0099200-5

172. Ahmado A, Carr AJ, Vugler AA, et al. Induction of differentiation by pyruvate and DMEM in the human retinal pigment epithelium cell line ARPE-19. Invest Ophthalmol Vis Sci. 2011;52 (10):7148-7159. doi:10.1167/iovs.10-6374

173. Güemes M, Rahman SA, Hussain K. What is a normal blood glucose? Arch Dis Child. 2016;101(6):569-574. doi:10.1136/ archdischild-2015-308336

174. Wierusz-Wysocka B, Wysocki H, Wykretowicz A, Klimas R. The influence of increasing glucose concentrations on selected functions of polymorphonuclear neutrophils. Acta Diabetol Lat. 1988;25(4):283-288. doi:10.1007/BF02581126

175. Oldenborg PA, Sehlin J. The glucose concentration modulates $\mathrm{N}$-formyl-methionyl-leucyl-phenylalanine (fMet-Leu-Phe)stimulated chemokinesis in normal human neutrophils. Biosci Rep. 1999;19(6):511-523. doi:10.1023/A:1020286010551

176. Nielson CP, Hindson DA. Inhibition of polymorphonuclear leukocyte respiratory burst by elevated glucose concentrations in vitro. Diabetes. 1989;38(8):1031-1035. doi:10.2337/ diabetes.38.8.1031

177. Dobos GJ, Andre M, Böhler J, et al. Inhibition of C5a-induced actin polymerization, chemotaxis, and phagocytosis of human polymorphonuclear neutrophils incubated in a glucose-based dialysis solution. Adv Perit Dial. 1993;9:307-311.

178. Menegazzo L, Ciciliot S, Poncina N, et al. NETosis is induced by high glucose and associated with type 2 diabetes. Acta Diabetol. 2015;52(3):497-503. doi:10.1007/s00592-014-0676-x

179. Joshi MB, Lad A, Bharath Prasad AS, Balakrishnan A, Ramachandra L, Satyamoorthy K. High glucose modulates IL-6 mediated immune homeostasis through impeding neutrophil extracellular trap formation. FEBS Lett. 2013;587 (14):2241-2246. doi:10.1016/j.febslet.2013.05.053

180. Furukawa S, Saito H, Matsuda T, et al. Relative effects of glucose and glutamine on reactive oxygen intermediate production by neutrophils. Shock. 2000;13(4):274-278. doi:10.1097/00024382200004000-00004

181. Edlow DW, Sheldon WH. The $\mathrm{pH}$ of inflammatory exudates. Proc Soc Exp Biol Med. 1971;137(4):1328-1332. doi:10.3181/ 00379727-137-35782

182. Hays RC, Mandell GL. PO2, pH, and redox potential of experimental abscesses. Proc Soc Exp Biol Med. 1974;147(1):29-30. doi:10.3181/00379727-147-38275

183. Gabig TG, Bearman SI, Babior BM. Effects of oxygen tension and $\mathrm{pH}$ on the respiratory burst of human neutrophils. Blood. 1979;53(6):1133-1139. doi:10.1182/blood.V53.6.1133.1133

184. Westman JA. Influence of $\mathrm{pH}$ and temperature on the luminol-dependent chemiluminescence of human polymorphonuclear leucocytes. Scand J Clin Lab Invest. 1986;46(5):427-434.
185. Naffah de Souza C, Breda LCD, Khan MA, et al. Alkaline pH promotes NADPH oxidase-independent neutrophil extracellular trap formation: a matter of mitochondrial reactive oxygen species generation and citrullination and cleavage of histone. Front Immunol. 2017;8:1849. doi:10.3389/fimmu.2017.01849

186. Maueröder C, Mahajan A, Paulus S, et al. Ménage-à-Trois : ménage-à-Trois: the ratio of bicarbonate to $\mathrm{CO} 2$ and the $\mathrm{pH}$ regulate the capacity of neutrophils to form NETs. Front Immunol. 2016;7:583. doi:10.3389/fimmu.2016.00583

187. Phelps P, Stanislaw D. Polymorphonuclear leukocyte motility in vitro. I. Effect of $\mathrm{pH}$, temperature, ethyl alcohol, and caffeine, using a modified Boyden chamber technic. Arthritis Rheum. 1969;12(3):181-188. doi:10.1002/art.1780120304

188. Gyllenhammar H. Effects of extracellular $\mathrm{pH}$ on neutrophil superoxide anion production, and chemiluminescence augmented with luminol, lucigenin or DMNH. J Clin Lab Immunol. 1989;28 (2):97-102.

189. Leblebicioglu B, Lim JS, Cario AC, Beck FM, Walters JD. pH changes observed in the inflamed gingival crevice modulate human polymorphonuclear leukocyte activation in vitro. J Periodontol. 1996;67(5):472-477. doi:10.1902/ jop.1996.67.5.472

190. Serrano CV, Fraticelli A, Paniccia R, et al. $\mathrm{pH}$ dependence of neutrophil-endothelial cell adhesion and adhesion molecule expression. Am J Physiol. 1996;271(3):C962-C970. doi:10.1152/ajpcell.1996.271.3.C962

191. Geffner JR, Trevani AS, Minnucci F, Palermo MS, Maugeri N, Isturiz MA. Extracellular acidic $\mathrm{pH}$ modulates oxygen-dependent cytotoxic responses mediated by polymorphonuclear leucocytes and monocytes. Clin Exp Immunol. 1993;91(1):164-169. doi:10.1111/j.1365-2249.1993.tb03373.x

192. Sitkovsky M, Lukashev D. Regulation of immune cells by local-tissue oxygen tension: HIF1 alpha and adenosine receptors. Nat Rev Immunol. 2005;5(9):712-721. doi:10.1038/ nri1685

193. Campbell EL, Bruyninckx WJ, Kelly CJ, et al. Transmigrating neutrophils shape the mucosal microenvironment through localized oxygen depletion to influence resolution of inflammation. Immunity. 2014;40(1):66-77. doi:10.1016/j.immuni.2013.11.020

194. Lone AG, Atci E, Renslow R, et al. Staphylococcus aureus induces hypoxia and cellular damage in porcine dermal explants. Infect Immun. 2015;83(6):2531-2541. doi:10.1128/ IAI.03075-14

195. Mecklenburgh KI, Walmsley SR, Cowburn AS, et al. Involvement of a ferroprotein sensor in hypoxia-mediated inhibition of neutrophil apoptosis. Blood. 2002;100(8):3008-3016. doi:10.1182/blood-2002-02-0454

196. Dyugovskaya L, Polyakov A, Ginsberg D, Lavie P, Lavie L. Molecular pathways of spontaneous and TNF-\{alpha\}-mediated neutrophil apoptosis under intermittent hypoxia. Am J Respir Cell Mol Biol. 2011;45(1):154-162. doi:10.1165/rcmb.2010-0025OC

197. Cho YD, Park SJ, Choi SH, et al. The inflammatory response of neutrophils in an in vitro model that approximates the postcardiac arrest state. Ann Surg Treat Res. 2017;93(4):217-224. doi:10.4174/astr.2017.93.4.217

198. Cross A, Barnes T, Bucknall RC, Edwards SW, Moots RJ. Neutrophil apoptosis in rheumatoid arthritis is regulated by local oxygen tensions within joints. $J$ Leukoc Biol. 2006;80 (3):521-528. doi:10.1189/jlb.0306178

199. Walmsley SR, Print C, Farahi N, et al. Hypoxia-induced neutrophil survival is mediated by HIF-1alpha-dependent NF-kappaB activity. $J$ Exp Med. 2005;201(1):105-115. doi:10.1084/ jem.20040624

200. Hannah S, Mecklenburgh K, Rahman I, et al. Hypoxia prolongs neutrophil survival in vitro. FEBS Lett. 1995;372(2-3):233-237. doi:10.1016/0014-5793(95)00986-J 
201. Branitzki-Heinemann K, Möllerherm H, Völlger L, et al. Formation of neutrophil extracellular traps under low oxygen level. Front Immunol. 2016;7:518. doi:10.3389/ fimmu.2016.00518

202. Ong CWM, Fox K, Ettorre A, Elkington PT, Friedland JS. Hypoxia increases neutrophil-driven matrix destruction after exposure to Mycobacterium tuberculosis. Sci Rep. 2018;8 (1):11475. doi:10.1038/s41598-018-29659-1

203. McGovern NN, Cowburn AS, Porter L, et al. Hypoxia selectively inhibits respiratory burst activity and killing of Staphylococcus aureus in human neutrophils. J Immunol. 2011;186(1):453-463. doi:10.4049/jimmunol.1002213

204. Suzuki Y, Aoki T, Takeuchi O, et al. Effect of hyperoxia on adhesion molecule expression in human endothelial cells and neutrophils. Am $J$ Physiol. 1997;272(3 Pt 1):L418-L425. doi:10.1152/ajplung.1997.272.3.L418

205. Wang GL, Jiang BH, Rue EA, Semenza GL. Hypoxia-inducible factor 1 is a basic-helix-loop-helix-PAS heterodimer regulated by cellular O2 tension. Proc Natl Acad Sci U S A. 1995;92 (12):5510-5514. doi:10.1073/pnas.92.12.5510

206. Jaakkola P, Mole DR, Tian YM, et al. Targeting of HIF-alpha to the von Hippel-Lindau ubiquitylation complex by $\mathrm{O} 2$-regulated prolyl hydroxylation. Science. 2001;292(5516):468-472. doi:10.1126/science. 1059796

207. Cockman ME, Masson N, Mole DR, et al. Hypoxia inducible factor-alpha binding and ubiquitylation by the von Hippel-Lindau tumor suppressor protein. $J$ Biol Chem. 2000;275 (33):25733-25741. doi:10.1074/jbc.M002740200

208. Hanauske-Abel HM, Günzler V. A stereochemical concept for the catalytic mechanism of prolylhydroxylase: applicability to classification and design of inhibitors. $J$ Theor Biol. 1982;94 (2):421-455. doi:10.1016/0022-5193(82)90320-4

209. Semenza GL, Roth PH, Fang HM, Wang GL. Transcriptional regulation of genes encoding glycolytic enzymes by hypoxia-inducible factor 1. $J$ Biol Chem. 1994;269 (38):23757-23763.

210. Cramer T, Yamanishi Y, Clausen BE, et al. HIF-1alpha is essential for myeloid cell-mediated inflammation. Cell. 2003;112 (5):645-657. doi:10.1016/S0092-8674(03)00154-5

211. Kong T, Eltzschig HK, Karhausen J, Colgan SP, Shelley CS. Leukocyte adhesion during hypoxia is mediated by HIF-1-dependent induction of beta2 integrin gene expression. Proc Natl Acad Sci U S A. 2004;101(28):10440-10445. doi:10.1073/pnas.0401339101

212. Karin M, Lin A. NF-kappaB at the crossroads of life and death. Nat Immunol. 2002;3(3):221-227. doi:10.1038/ni0302-221

213. Hoenderdos K, Lodge KM, Hirst RA, et al. Hypoxia upregulates neutrophil degranulation and potential for tissue injury. Thorax. 2016;71(11):1030-1038. doi:10.1136/thoraxjnl-2015207604

214. Grutkoski PS, Graeber CT, D’Amico R, Keeping H, Simms HH. Regulation of IL-8RA (CXCR1) expression in polymorphonuclear leukocytes by hypoxia/reoxygenation. J Leukoc Biol. 1999;65 (2):171-178. doi:10.1002/jlb.65.2.171

215. Derevianko A, D’Amico R, Simms H. Polymorphonuclear leucocyte (PMN)-derived inflammatory cytokines-regulation by oxygen tension and extracellular matrix. Clin Exp Immunol. 1996;106 (3):560-567. doi:10.1046/j.1365-2249.1996.d01-871.x

216. Koehne P, Willam C, Strauss E, Schindler R, Eckardt KU, Bührer C. Lack of hypoxic stimulation of VEGF secretion from neutrophils and platelets. Am J Physiol Heart Circ Physiol. 2000;279(2):H817-H824.

217. Moran EM, Heydrich R, Ng CT, et al. IL-17A expression is localised to both mononuclear and polymorphonuclear synovial cell infiltrates. PLoS One. 2011;6(8):e24048. doi:10.1371/journal. pone. 0024048
218. Knowles R, Keeping H, Nguyen K, Garner C, D’Amico R, Simms HH. Hypoxemia up-regulates interleukin-8 stimulated phagocytosis of polymorphonuclear leukocytes by differential regulation of $\mathrm{CD} 32 \mathrm{w}$ and $\mathrm{CD} 35$ messenger RNA expression. Surgery. 1995;118(2):177-184. doi:10.1016/S0039-6060(05) 80321-6

219. Marwick JA, Dorward DA, Lucas CD, et al. Oxygen levels determine the ability of glucocorticoids to influence neutrophil survival in inflammatory environments. J Leukoc Biol. 2013;94 (6):1285-1292. doi:10.1189/jlb.0912462

220. Scannell G, Waxman K, Vaziri ND, et al. Hypoxia-induced alterations of neutrophil membrane receptors. J Surg Res. 1995;59 (1):141-145. doi:10.1006/jsre.1995.1145

221. Rotstein OD, Fiegel VD, Simmons RL, Knighton DR. The deleterious effect of reduced $\mathrm{pH}$ and hypoxia on neutrophil migration in vitro. J Surg Res. 1988;45(3):298-303. doi:10.1016/00224804(88)90079-0

222. Mandell GL. Effect of temperature on phagocytosis by human polymorphonuclear neutrophils. Infect Immun. 1975;12 (1):221-223. doi:10.1128/IAI.12.1.221-223.1975

223. Peterson PK, Verhoef J, Quie PG. Influence of temperature on opsonization and phagocytosis of staphylococci. Infect Immun. 1977;15(1):175-179. doi:10.1128/IAI.15.1.175-179.1977

224. Sebag J, Reed WP, Williams RC. Effect of temperature on bacterial killing by serum and by polymorphonuclear leukocytes. Infect Immun. 1977;16(3):947-954. doi:10.1128/IAI.16.3.947-954.1977

225. Charo IF, Yuen C, Goldstein IM. Adherence of human polymorphonuclear leukocytes to endothelial monolayers: effects of temperature, divalent cations, and chemotactic factors on the strength of adherence measured with a new centrifugation assay. Blood. 1985;65(2):473-479. doi:10.1182/blood.V65.2.473.473

226. Black CD, Cook JA, Russo A, Samuni A. Superoxide production by stimulated neutrophils: temperature effect. Free Radic Res Commun. 1991;12-13(Pt 1):27-37. doi:10.3109/107157691 09145764

227. Tennenberg SD, Zemlan FP, Solomkin JS. Characterization of $\mathrm{N}$-formyl-methionyl-leucyl-phenylalanine receptors on human neutrophils. Effects of isolation and temperature on receptor expression and functional activity. J Immunol. 1988;141 (11):3937-3944.

228. Mehta J, Spilberg I. Heterologous receptor population for a chemotactic factor F-Met-Leu-Phe on the human neutrophil. Effect of pH and temperature. Inflammation. 1983;7(3):301-309. doi:10.1007/BF00917267

229. Shalekoff S, Page-Shipp L, Tiemessen CT. Effects of anticoagulants and temperature on expression of activation markers CD11b and HLA-DR on human leukocytes. Clin Diagn Lab Immunol. 1998;5(5):695-702. doi:10.1128/CDLI.5.5.695-702.1998

230. Fujiwara Y, Okamura Y. Temperature-sensitive gating of voltage-gated proton channels. Curr Top Membr. 2014;74:259-292.

231. DeCoursey TE, Cherny VV. Temperature dependence of voltage-gated $\mathrm{H}+$ currents in human neutrophils, rat alveolar epithelial cells, and mammalian phagocytes. J Gen Physiol. 1998;112(4):503-522. doi:10.1085/jgp.112.4.503

232. Zhao D, Meng X, Cai C, Yuan C, Zou F. Temperature pretreatment alters the polarization response of human neutrophils to the chemoattractant N-formyl-Met-Leu-Phe. Inflammation. 2009;32 (1):47-56. doi:10.1007/s10753-008-9101-3

233. Power G, Moore Z, O'Connor T. Measurement of $\mathrm{pH}$, exudate composition and temperature in wound healing: a systematic review. J Wound Care. 2017;26(7):381-397. doi:10.12968/ jowc.2017.26.7.381

234. Severns C, Collins-Lech C, Sohnle PG. Effect of temperature on production of hypochlorous acid by stimulated human neutrophils. J Lab Clin Med. 1986;107(1):29-35. 


\section{Publish your work in this journal}

The Journal of Inflammation Research is an international, peerreviewed open-access journal that welcomes laboratory and clinical findings on the molecular basis, cell biology and pharmacology of inflammation including original research, reviews, symposium reports, hypothesis formation and commentaries on: acute/chronic inflammation; mediators of inflammation; cellular processes; molecular mechanisms; pharmacology and novel anti-inflammatory drugs; clinical conditions involving inflammation. The manuscript management system is completely online and includes a very quick and fair peerreview system. Visit http://www.dovepress.com/testimonials.php to read real quotes from published authors. 